\title{
TENURE TRANSITIONS AT THE EDGES OF OWNERSHIP: REINFORCING OR CHALLENGING THE STATUS QUO?
}

\author{
Rachel Ong ViforJ, Curtin University, rachel.viforj@curtin.edu.au \\ William A.V. Clark, University of California, Los Angeles \\ Susan J. Smith, Cambridge University \\ Gavin Wood, RMIT University \\ William Lisowski, Independent scholar \\ N.T. Khuong Truong, Curtin University \\ Melek Cigdem, RMIT University
}

\section{Keywords:}

Home ownership, tenure transitions, Australia, UK, USA

\section{Acknowledgements}

This paper the Household, Income and Labour Dynamics in Australia (HILDA) Survey, British Household Panel Survey (BHPS), UK Household Longitudinal Study (UKHLS) and Panel Study of Income Dynamics (PSID). HILDA is funded by the Australian Department of Social Services and managed by the Melbourne Institute of Applied Economic and Social Research. The BHPS and UKHLS are collected by the Institute for Social and Economic Research. The collection of PSID data is funded by the National Science Foundation under awards SES1157698 and SES1623684. The views expressed herein belong to the authors and should not be attributed to the data or funding agencies.

\section{Funding}

This research was supported by the Australian Research Council (ARC)'s Discovery Projects funding scheme (DP190101461). Rachel Ong ViforJ is the recipient of an ARC Future Fellowship (FT200100422).

\section{Authors declare no conflict of interests.}

\begin{abstract}
This paper provides an empirical overview of housing tenure transitions in Australia, the UK and the USA during a period of unprecedented economic instability in 2001-2017. Focusing on the neglected theme of episodic home ownership, we profile those who straddle the tenure divide by moving into and out of renting from time to time. Using panel data we model this 'churn' in three jurisdictions, showing that even the dislocation of a global financial crisis does not eclipse the independent impact of life events during rental spells. We find that, whatever individuals bring from prior ownership, shocks occurring during a rental spell - unemployment, loss of a partner, additional dependent children - can be sufficient to prevent return. Churning is also health- and age- selective, adding 'drop-out' among the old to 'lock-out' for the young as a policy concern. Even those who successfully regain owner-occupation increase their credit and investment risks without necessarily improving their housing position. Overall 'churners' are a diverse constituency whose life chances are powerfully shaped by episodic ownership: what they share is time spent in an unacknowledged, under-instituted space between tenures where there is latent demand for innovative financial services, and untapped potential for radical policy shifts.
\end{abstract}




\section{Introduction}

In the majority of jurisdictions of the more developed world, there has, for close to a century, been an uneasy political consensus around the wisdom of anchoring housing systems on owner-occupation. The mix of discursive and practical acts positioning owner-occupation at the heart of housing and public policy has been especially pronounced in the English-speaking world where it is traced out in some detail for the UK (Ronald, 2008; Smith, 2008), Australia (Wood and Ong, 2017; Pawson et al., 2019) and USA (Clark, 2011; Blatt, 2012). This normalization of home ownership dates from at least the 1930s, when mortgage finance offered borrowers a means of spreading incomes across the life course. It gained impetus half a century later when owned homes proved unexpectedly effective for wealth accumulation, and reached an apogee in the early 2000s as housing assets, or more correctly mortgage debts, formed households' de facto financial buffer in a world of reducing welfare transfers and polarizing incomes (Smith and Searle, 2010).

This status quo began to unravel in the early 2000s as the most pronounced, globally coordinated cycle of house price appreciation in history gave way to the first major international financial shock anchored in debt-funded property markets (Renaud and Kim, 2007). In the wake of that crisis, in tandem with the startling recovery of residential property prices (Fernandez and Aalbers, 2017), owner-occupation began to shrink at the margins and attract criticism for its exclusionary, unequalising impacts as well as for its precarity and its paradoxical, contradictory effects (Arundel and Ronald, 2020; Fikse and Aalbers, 2020; Ronald et al., 2017; Smith, 2015).

A key focus has rightly been the steep decline in access and affordability that is locking out the young, giving rise to 'generation rent' and a resurgence of rentierism (Christophers, 2019a). The parallel risk of 'drop-out' underlined by the USA's farreaching foreclosure crisis has been less comprehensively documented, perhaps because the likelihood of leaving owner-occupation was lower in the lead up to, and immediate aftermath of, the GFC than might have been predicted from previous cycles (Wood et al., 2017). Equally thought-provoking is the discovery that among those who did drop out, a surprisingly high proportion - two-thirds in Australia and over a half in the UK - returned, even over a short time horizon (Wood et al., 2013). These churners are owners who straddle the tenure divide by moving into and out of renting from time to time (at least once but sometimes on multiple occasions). These re-entry rates are comparable with those in an earlier, less volatile, climate in the USA (Dieleman et al., 1995) and consistent with those more recently observed in the USA (Perkins, 2018) as well as in the present analysis (below). As the drift to post-homeownership looms large (Ronald and Kadi, 2017), it is worth looking more closely at this unanticipated permeability of the tenure divide. 'Churning' may simply reflect a scramble to retain business as usual for the dominant tenure sector; but, as we shall see, it may be a signal from the margins of the need, appetite and potential for housing systems to change.

To explore this we first profile the neglected edges of ownership, reflecting on what their changing shape might mean for the fortunes of individuals and housing system structures. We then report modelling estimates that identify, over nearly two decades across three jurisdictions, key drivers of episodic ownership during a period of 
unprecedented economic instability. Building on research that has already established the predictors of exit, we focus on the factors present on return, and report on the impacts of such 'churn'. We conclude with a case for better recognising and more formally instituting the edges of ownership to support households at the margins, and to enable some more far-reaching policy shifts.

\section{The edges of ownership}

The edges of ownership have recently come under intense scrutiny, reflecting the growing proportion of households who cannot attain owner-occupation, quite apart from those at risk of dropping out. Although there is a large literature on tenure transitions, rooted in the foundational work of Henderson and Ioannides $(1983,1989)$, the practice we call 'churning' or episodic ownership has barely been explored. It arises because, as Wood et al. (2013) put it: 'the edges of ownership are in flux' (p3), creating an unacknowledged, under-explored and largely uninstituted zone of lived experience between tenures.

Churners are not the only group who oscillate around the tenure divide. A 'third way' represented by shared and co-ownership schemes is well-researched (Monk and Whitehead, 2011). However, these schemes occupy a niche at the margins without challenging the dominant model, whereas churning is widespread and unsettling to the political imagination. When households routinely inhabit a zone at the margins that is not sharply tenure bound, it challenges ingrained assumption of a linear pathway to outright ownership. Haffner et al. (2017) thus position churning as a liminal zone 'which is neither fully owned nor wholly rented, and which is replete with both pitfalls and opportunities'(p174) pertaining to the fortunes of individuals, the structure of whole societies, and the future of housing and urban policy.

Churners, of course, have varied motivations and aspirations. There is, indeed, an extent to which households' trajectories are 'naturally' iterative across tenures. Sellers may temporarily drop out of ownership to manage the pace of the market, or relocate for employment, for example. Likewise, biographical disruptions, especially divorce or separation, are well-reported drivers of residential mobility, during which 'churning' might feature, for one partner at least (Clark 2013a, Mikolai and Kulu 2018). Churning is, on the other hand, one of few ways of adjusting housing outlays to stagnating incomes, or managing economic shocks when borrowing is exhausted. Effectively, it enables households at the margins of ownership to manage financial stress by temporarily swapping the costs of owning for the outlays of renting. During most of the study period the former exceeded the latter, though the balance of course varies with shifts in all the elements that make up the user cost of housing.

In all these circumstances, rental spells might be expensive and unwieldy, but can add flexibility for sellers, buy time, and may even signal the efficient operation of housing systems. At the same time, those exiting owner-occupation face exposure to risks whilerenting, added transactions costs, and new threshold tests which might impact selectively on the opportunity to return. Empirically it is worth exploring these frictions if only to expose gaps in housing policy or financial services that could readily be addressed. 
There is also a conceptual case for scrutinising episodic ownership, not least to inform emerging debates about the possibility that, as conventional oppositions between capital and labour dissolve (Berman and Milanovic, 2020), any subsequent restructuring will play out around housing. There is already evidence of a rift within owner-occupation between those in the mainstream who pay down their mortgage and those on the margins who accumulate debt (Wood et al., 2013, Forrest and Hiriyama, 2018). More recently Adkins et al (2019), rekindled an interest in neo-Weberian class structuration, by positioning 'churners' squarely on the break between the haves and the have-nots in a new asset-based hierarchy. Although we cannot discriminate between churners who consciously insert themselves between tenures, and those clinging desperately onto owner-occupation, we can look for evidence that churners share a common structural niche in an under-instituted space between tenures. If we find factors associated with rental spells that are decisive for the future, it will add weight to those questioning a status quo that rests on a sharp, unequalising, tenure divide (Christophers, 2019b).

\section{Episodic owner-occupation in Australia, the UK and the USA}

To explore the character and effects of episodic owner-occupation we interrogate the national panel surveys of three 'iconic' home ownership societies: Australia, the UK and the USA. These jurisdictions have relatively high ownership rates (60-70\%), though below those achieved through large-scale stock transfers in Eastern Europe. They also show relatively high levels of mortgage debt, though here they are eclipsed by the north Europeans, particularly Netherlands, Norway, and Denmark ${ }^{1}$. What distinguishes them is their position within an English-speaking world which formed the crest of a wave of mortgaged owner-occupation sweeping through the more developed economies in the late $20^{\text {th }}$ century. Their governments also showed some success in restoring 'business as usual' after the Global Financial Crisis (GFC), and all have subsequently seen a steady if modest decline in rates of owner-occupation (Arundel and Ronald, 2020; Smith et al., 2021). These countries are, then, above all, a litmus test for the fortunes of ownershipcentred housing systems, in which perhaps the most influential shared institutional factor is an entrenched tenure divide.

There are, of course, some important institutional differences between them. The most salient are the configuration and regulation of mortgage markets, and the size and structure of their rented sectors. The USA approached the 2000s with less complete, more poorly regulated mortgage markets than Australia or the UK, as well as higher indebtedness and greater exposure to the subprime sector. All else equal, therefore, we would expect an event like the GFC to increase the risks of exit from home ownership, and depress the likelihood of returning, particularly in the USA. On the other hand, the USA, like Australia, has a large private rental sector, to 'oil the wheels' of tenure transitions, whereas the UK has a well-established tradition of social renting, which could be considered a 'soft landing' for those who drop out of ownership, and thus a disincentive to churn. Finally, in Australia, and to a lesser extent the UK, pension wealth inserts itself into this equation, providing lump sums that can be brought forward or held in reserve to manage tenure transitions if needed.

\footnotetext{
${ }^{1}$ See https://data.oecd.org/hha/household-debt.htm
} 
Pragmatically, this three-country review is aided by the fact that each jurisdiction has a well-established national panel survey with relatively long runs of data in the Household, Income and Labour Dynamics in Australia Survey (HILDA), the British Household Panel Survey (BHPS) together with its successor, the UK Household Longitudinal Study (UKHLS), and the USA's Panel Study of Income Dynamics (PSID). These surveys are similar in structure, use common data collection methods, and were to an extent designed for comparability (Watson and Wooden, 2020). They are not the only long-running, widely accessible panel surveys available; indeed they are now harmonised with those in Germany, South Korea, Russia and Switzerland (Turek et al., 2021). There is the future prospect therefore to add the perspective of quite differently structured housing systems, lower ownership rate countries or emerging economies with immature mortgage markets, for example. Nevertheless, in this study there is an unprecedented opportunity to link biographical shifts, financial shocks, and other life events to housing transitions across what might be the very zenith of owner-occupation in the more developed world.

To explore tenure transitions at the edges of ownership, we constructed an unbalanced panel of 5,885 Australian, 4,270 British and 5,836 American individuals, surveyed annually during 2001-2017 in HILDA, 2001-2008 in BHPS and 2010-2017 in the UKHLS, and biannually from 2001 to 2017 in the PSID. The strengths and limitations of these instruments are by now well-documented: see our supplementary materials for notes on their comparability. In this analysis, an individuals's observation window begins whenever they first appear between 2001-2017 as a home owner. If an individual is not recorded as a home owner during this period, they are excluded from the sample. For those retained the observation window ends in 2017, or the wave preceding an individual's death, whichever is earlier. This sample frame is designed to track housing pathways during and after a home ownership spell. The majority are 'ongoing owners' who, having entered owner-occupation before or during the e study period, remained in the sector to 2017. Our primary interest, however, is in the minority who dropped out of ownership - around 1 in 4 in Australia and the USA; under 1 in 5 in the UK - and in the relatively high proportion who later bought back in.

Because of this focus, while acknowledging that all panel surveys are subject to attrition (details of which are well-documented), we note that any difference in attrition rates between ex-homeowners and other tenure groups is less concerning than non-randomly distributed attrition within the sample of ex-homeowners. Testing for this, we find that attrition rates differ little across most characteristics, but are noticeably higher than average among older and widowed ex-homeowners (the two are correlated) - a point we return to later.

A statistically robust way to proceed is to estimate a random effects logit model ${ }^{2}$; following Ermisch and Di Salvo (1996) we use a tenure transition model, dropping cases with missing values for any variable, together with cases from the final year of the study (2017) as we are unable to observe whether they exit ownership in 2018 (being outside the observation period) ${ }^{3}$. The effects of attrition and missing values are milder within a

\footnotetext{
2 This specification estimates the independent influence of key variables on the likelihood of regaining ownership, while controlling for others and managing omitted variables (Allison, 2009).

${ }^{3}$ Explanatory variables are measured in the wave preceding that in which a renter's return to ownership (or not) is measured.
} 
transition model than an event history model. With the relevant filters applied, 1,420 individuals left ownership at some point in the Australian sample, 335 in the UK and 1,147 in the USA; of those, $71 \%, 50 \%$ and $59 \%$ respectively returned to ownership during 2001-2017: some left and returned more than once. To capture these trajectories, we work with 'person-years' of renting: in Australia, where those who left accumulated 5,511 person-years of renting, the average rate of transition back into ownership is $21 \%$; in Britain, with 1,427 person-years of renting, the rate is 13\%; and in the USA, with 2,963 person-years of renting, 24\%. The dependent variable is a binary of whether an exowner at $t$ had regained owner-occupation by $t+1$. For the UK and Australia, the interval ' $t$ ' is a year; for the USA, it is two years. Formally, the model quantifies the independent effects of each measured variable on the odds of an ex-owner returning to ownership in any given survey wave (conditional on renting during the previous wave, and having been an owner-occupier in one or more prior waves).

We have already established for Australia and the UK that those who drop out of ownership are disproportionately likely to report unemployment, relationship breakdown or deteriorating health, and to be young, less established, buyers, who proved vulnerable to debt effects (from high loan-to-value ratios) and to the GFC (Wood et al. 2017). Our present analysis takes up the narrative at the point where some of those who dropped out transition back in. What did it take, at a time when drop-out or lockout best characterised the edges of ownership, to buck the trend?

Key variables include: demographic and financial factors associated.with the loss of owner-occupation; life events while renting (partly identified by sequencing the postownership housing trajectories of like individuals in three of the surveys in Wood et al, 2013); and controls for institutional and macroeconomic influences. These latter include year fixed effects (to control for duration of rental spells) ${ }^{4}$, and the user cost of housing to help account for patterns of return to ownership across the GFC ${ }^{5}$. There are also controls for region (Table S2) and race/ethnicity, though panel surveys are unsuited to spatial nuance, while counts are quickly lost when tracking minority populations.

Independent variables are measured in binary or continuous form. Binary predictors take on a value of 1 when the characteristic is present, 0 otherwise. The include age bands (under 35, 65 or over, and each intervening decade; ethnicity; marital status; lost partner while renting; dependent children; added children while renting; health status; tertiary qualification; employed; lost employment while renting; housing tenure binaries (private rental, social housing and rent-free); geographical region and calendar year binaries

In addition, two spell-invariant variables are measured in the final year of those home ownership spells preceding a rental spell: real amounts of housing equity released upon

\footnotetext{
${ }^{4}$ The longer the rental spell the less likely it is to end; towards the end of the observation period, longer spells dominate, artefactually reducing the rate of return overall. Year fixed effects control for these duration dependence effects. Controls for spell duration add econometric challenges without improving the model.

${ }^{5}$ This avoids the need for a pre- and post-GFC dummy which would be collinear with year fixed effects,
} 
selling up (in 2017 prices and thousands) and the user cost of capital, expressed as ${ }^{6}$ :

$$
\begin{array}{ll}
u=(1-\tau) i+\tau i \alpha+\vartheta-\pi_{h} & (1: A U S, U K) \\
u=(1-\tau) i+\vartheta-\pi_{h} & (2: U S A)
\end{array}
$$

where

$u=$ home owner's user cost

$\tau=$ marginal income tax rate of home owner

$i=$ home loan interest rate

$\alpha=$ loan-to-value ratio

$=$ operating costs

$\pi_{h}=$ house price appreciation rate

For further details see Tables $\mathrm{A} 1, \mathrm{~A} 2$ and $\mathrm{S} 1^{7}$. To measure the outcome, we define an individual's housing tenure on a 'person-year' basis (note that if a sample member is identified in a given year as a home owner, the individual's co-resident partner is also assigned home owner status in that year). The same is true for tenants who on a year by year basis are identified as either social renters (paying rent to social housing landlords), private renters (including those paying board to another household member) or rentfree,

Table 1 reports the results of the preferred, best-fit model; the full results for all models are listed in Tables S4-S6. Throughout we use easy-to-interpret odds ratios: the more the ratio departs from 1, the more being in one category lifts (if greater than 1) or depresses (if less than 1) the odds of returning.

[Table 1]

\section{Key findings}

It might be anticipated that the biggest influence on the likelihood of regaining owneroccupation, having dropped out across a major dislocation like the GFC, would be that crisis. It is certainly true that year-on-year across the study period, the proportion of leavers who returned declined - from $47 \%$ to $15 \%$ in Australia, $44 \%$ to $9 \%$ in the UK, and $38 \%$ to $22 \%$ in the USA (Table S3). This, however, mainly reflects the growing importance of longer rental spells which (as noted above) diminish the pooled odds of returning as we approach the end of the study period. What we also observe, however, is a drop across the GFC in all countries' interest rates (Figure S1). Interest rates peaked around 2007 and fell sharply thereafter, especially in the USA as monetary policy relaxed. So despite rising unemployment, falling real incomes, and a generally deteriorating macroeconomic environment, we expect any GFC effect on regaining owner-occupation to have been partly mitigated by a dip in the user costs of owning a home.

Turning to spatial variation, the fitted models confirm the greater likelihood of regaining owner-occupation in lower priced regions in Australia (where, compared to being in

\footnotetext{
6 The second term on the right-hand side of equation (1) is the tax penalty associated with debt finance because interest is not deductible from assessable income in Australia and the UK. It disappears in equation (2) because in the USA mortgage interest is deductible and capital gains are exempt provided they are rolled over into a subsequent housing purchase.

${ }^{7}$ As well as tables within the main text, we refer to findings in the appendix (A), and supplementary materials (S).
} 
Sydney, living in Perth or Adelaide helps) and the USA (where living in the east and west South Central regions is more conducive to return than being in a South Atlantic state). In the UK, on the other hand, rates of return are lower in less affluent areas that typically have larger social housing stocks. Panel surveys are not the best way to address the geography of churning, and for now therefore we regard these indicators as controls. Importantly, we find, even with year, user cost and regional controls in the model, a range of microeconomic and social factors whose impacts at the edges of ownership are substantial and not swamped by shocks or contours in the wider economy. Three salient themes are captured in Table 1.

\subsection{Appetite for debt}

Very few churners exited ownership with sufficient capital to re-enter as outright owners. Between 2001 and 2017, churners in Australia, the UK and the USA, on exiting owner-occupation, released an average of AU $\$ 379 \mathrm{k}, £ 166 \mathrm{k}$ and US $\$ 96 \mathrm{k}$ respectively at 2017 prices. However, they paid mean real prices of AU\$596k, $£ 240 \mathrm{k}$ and US\$266k respectively upon return. The majority bridged the gap by taking out a larger mortgage - AU $\$ 53 \mathrm{k}, £ 19 \mathrm{k}$ and US\$10k larger than the one they had previously paid off (see Table 2). It might therefore be expected that measures tapping into ability to secure and sustain a mortgage would be important in discriminating between lasting leavers and churners.

Employment is key among these. However, while being employed in itself raises the odds of re-entry in Australia and the USA by nearly $50 \%$ in Australia and over one-third in the USA, what is decisive in locking people out is losing employment during a rental spell. Job loss while renting depresses the likelihood of a return to ownership by $60-70 \%$ in all three countries compared with those employed during their rental spell. There is also evidence that employability (as indexed by tertiary education) matters, especially in the UK where, although less widely held than in the other two countries, tertiary qualifications make the biggest single positive difference to the odds of return to ownership. Here higher education more than doubles the likelihood of successful return; the uplift is $36 \%$ and $48 \%$ in Australia and the USA respectively.

\subsection{A substantial equity injection}

A second important condition of return to ownership is the ability to assemble a lump sum to inject into a new property, not least to keep borrowing at manageable levels. Table 2 shows that, as well as borrowing up, Australian churners typically inject as much as AU $\$ 390 \mathrm{k}, \mathrm{UK} £ 170 \mathrm{k}$ and US\$113k, when they return to ownership. To that end, the modeling exercise suggests that the amount of equity extracted when previously owned homes are sold is particularly important in Australia and the USA (in the UK the effect is in the same direction but statistically insignificant). Quite simply, the more equity that is released and safeguarded to roll back into a future purchase, the better the chances of return. Every 100k (AU/US\$) of equity released raises the odds of returning by $5 \%$ and $11 \%$ in Australia and the USA respectively.

In the UK high housing costs prior to exit, as measured by the user cost of owneroccupation, are important. High user costs imply that a home occupier may be better off renting than owning, perhaps itself motivating exits from ownership. That aside, high 
user costs in the year prior to exit are likely to discourage the accumulation of the lump sums that most returners need. So as well as precipitating exit, high user costs might also inhibit return. This appears to be the case in the UK where, notwithstanding macroeconomic shifts, user costs are the financial predictor most affecting the likelihood of reentry - the counterpart perhaps to the equity extracted on sale that matters more in Australia and the USA.

\section{[Table 2]}

While equity roll-over from a previous ownership spell is a necessary condition of return, it is rarely sufficient. For the most part, churners make larger equity injections into their new home (on average AU\$11k more in Australia, £5k in the UK and US\$18k in the USA) than they extracted from their last property (Table 2). It might be thought that one obvious source of such funds would be inheritances or inter vivos parental gifts. Although the number of people receiving these during a rental spell is low (Table A1), the variables signaling windfall gains from inheritance (which cannot be measured for the UK) are significant and substantial - indeed they make the largest positive difference - in the Australian and American samples. Bringing pension payouts forward is another possible source of equity injection on return ${ }^{8}$, and although there is no way to identify such tactics in our dataset, some of the age effects discussed later may imply this feature in Australia, at least.

In the absence of a windfall, the indications in the data are that having the opportunity to conserve wealth and/or save funds is key. As well as retaining employment, another financial factor with a decisive bearing on ability to save, is the opportunity to live rentfree. In all three countries, churners are more likely to live rent-free than are lasting leavers: this practice significantly raises the odds of re-entry by $36 \%$ in Australia and $39 \%$ in the USA.

\subsection{Personal attributes}

A third set of observations relates to personal attributes, some of which may impact households' capacity to raise funds by accumulating savings or adding to mortgage debt. In societies divided by race, we would expect even proxy measures to matter, albeit mediated by institutions. In the UK, therefore, the odds of return are higher for minority ethnic groups than for their white counterparts, capturing a long tradition of low-income ownership among households of South Asian descent (partly reflecting their early exclusion from the social sector). In Australia, non-English speaking immigrants fare worse than English-speaking immigrants and the Australian-born consistent with a discrimination thesis. In the USA, there are no significant race-related differences reflecting perhaps the extent to which the main challenge for non-White Americans is getting into the sector at all. Even controlling for these important differences, we note some critical constraints on regaining owner-occupation related to the scale economies in two-person households, life cycle, dependent children, and health.

\footnotetext{
${ }^{8}$ Legislation in Australia and the UK potentially frees up pension funds at least for older mortgagors in financial need.
} 
First, we might expect the scale and specialization economies of two-person households to bring important financial advantages for households returning to owner-occupation (Brien and Sheran, 2003), as incomes are pooled and costs shared in ways rarely available to singletons. This certainly holds in the USA and Australia, where being separated or divorced, and to an even greater extent being single and never married, substantially and significantly reduces the odds of returning to ownership compared with being married. In the USA, being widowed has a similar if more modest effect.

In the UK, uniquely, those who are single, divorced or separated are rather more likely than married couples to regain owner-occupation, probably for institutional reasons. The UK's social rented sector contains, at best, temporary shelter for singles. Private rental housing - the more likely destination following relationship breakdown - is, on grounds of cost alone, a powerful disincentive to singletons. This helps explain why, in the UK, financial scarring from prior relationship breakdown seems not to impair the prospects of future home purchase. Overriding this, however, is the fact that in all three jurisdictions the financial and wider shock of losing a partner while renting (in practice, mainly through break-up) is the most substantial household structure constraint on regaining owner-occupation. It reduces the odds of returning by $60 \%-70 \%$, reflecting both loss of scale economies and fall-out from wealth-splitting.

Second, life-cycle effects, best measured by categorising age, vary across jurisdictions. Uniquely in Australia, 55-64 years olds have a higher chance of returning to ownership than their younger counterparts. This could reflect the popularity of trading down to release equity (perhaps with a rental gap en route). However as this effect is specific to one country, it may also reflect the opportunity that Australians over the age of 55 have to draw from pension wealth for the lump sum that is important in returning to ownership 9 . Uniquely in the USA, 45-64 year olds have a lower likelihood of return than younger dropouts, perhaps, for the older end of that age group at least, signalling the diminishing likelihood of securing mortgage finance as retirement approaches. The most marked effect though is among US and UK over-65 dropouts, where the likelihood of returning from renting declines sharply to less than one-quarter and just over one-third, respectively, of that among the under-35s. This may be a retirement move-into-rental (or in the UK a 'move-into-sheltered housing') effect, or it could echo other pressures to drop out in later life which bear further scrutiny. As reported earlier, older, and widowed leavers in our sample are particularly vulnerable to attrition. It is likely that those subgroups with relatively high rates of attrition are also prone to drop out and churn because panel surveys find it more difficult to track participants after residential moves. But this suggests, if anything, that the results reported here under-estimate the ageselectivity of 'drop-out' and churn.

Third we turn to the question of dependent children the presence of which, in the USA slightly depresses the odds of regaining ownership while paradoxically in Australia, they have the opposite effect. This might reflect the fact that in Australia affluent households tend to have larger families, ${ }^{10}$ whereas in the UK and USA larger families imply greater financial stress (Fusco and Islam, 2017). In the UK and Australia alike however, a crucial

\footnotetext{
${ }^{9}$ Over the study period Australians could drawdown their pension from age 55, encouraged by tax advantaged transition-to-retirement schemes.

${ }^{10}$ According to the Australian Bureau of Statistics (Cat. 6523), median equivalised household disposable income in 2013-14 was AU\$66k and \$AU105k for couples with zero and three dependent children respectively.
} 
finding is that adding a child while renting - potentially increasing spending needs and perhaps reducing parental income at a critical point - significantly depresses the likelihood of returning to owner-occupation.

Finally, health and welfare measures indicate that although as might be expected, in all three countries, those who return to ownership tend to score better on health variables than those who do not. In Australia and the US having fair to poor, rather than good or very good health, reduces the chance of churning by about one-third and more than onefifth, respectively. This may reflect the extent to which poor health gives rise to pressing spending needs and also, through impacts on work, depresses household incomes to the extent that once such households drop out they are unable to assemble the resources required to return.

Health does not have a significant independent impact on the odds of regaining ownership in the UK though here the effects of poor health may be implicit in some other observations. For example, the models indicate that for leavers, being in social (rather than private) renting reduces the odds of returning to ownership, by around threequarters in the UK and two-thirds in Australia. This captures the twin effects of health selectivity into social renting (health needs offer one of few routes into the social sector that are open to those exiting owner-occupation), and the ability of the sector to deliver health-appropriate housing outcomes to those it accommodates (social renting in the UK, in particular, still offers protection from market rents, aims to meet household needs and implies security of tenure). In the USA a key consequence of ill-health for return to ownership is its financial cost, the effects of which are considered above; being in public rather than private rental has no independent effect.

\subsection{In summary}

This modelling exercise shows that, although the likelihood of exiting owner-occupation is increased by financial stress and biographical disruption, leavers in the opening two decades of the $21^{\text {st }}$ century had a high chance of return, conditional on effective stewardship of assets, an appetite for debt, and an uneventful rental spell. These conditions did, perhaps surprisingly, obtain for the majority during the study period. On the other hand, whatever individuals bring from prior ownership, shocks occurring during a rental spell - unemployment, loss of a partner, and the addition of dependent children - can be sufficient to lock them out. Churning is also, moreover, selective. In Australia and the USA, poor health is disproportionately associated with exiting owneroccupation and with failing to return. Likewise, in the UK and the USA, where young people are increasingly locked out, older leavers are least likely to return, subtly changing the demographics of the sector, even taking such attrition bias as we can detect (particularly among this latter group) into account,

In short, the empirical analysis implies that episodic ownership may operate as a sifting and sorting mechanism, differentiating owners from renters along a number of dimensions, both enlarging and winnowing out the edges of ownership as the sector shrinks in size. What then, of those who 'survive' this process?

\section{What churning achieves}


Here we consider the housing outcomes of leavers who successfully return to ownership. The signs are promising. Table 2 indicates that, on average, churning is associated with a real increase in home values (by AU $\$ 64 \mathrm{k}$ in Australia, $£ 24 \mathrm{k}$ in the UK and US\$28k in the USA) that exceeds the real uplift in mortgage debt (AU $\$ 53 \mathrm{k}, £ 19 \mathrm{k}$ and US $\$ 10 \mathrm{k}$ on average). Looking more closely for Australia, but not the UK and USA (where there is no equivalent to HILDA's wealth module), a snapshot of how churners' overall asset and debt position unfolds over time compared with that of ongoing owners and lasting leavers is given in Table 3. The indication is that ongoing owners build assets and contain debts, lasting leavers erode assets and run down loans, and churners grow both. Specifically, three points stand out.

\section{[Table 3]}

First, on the whole, churners build assets, gaining ground over time relative to leavers, though never quite catching up with ongoing owners. Between 2002 and 2014 the average total assets of churners' increased from some $50 \%$ above that of lasting leavers, to double. In contrast churners' assets were worth around 90\% of those owned by ongoing owners in both 2002 and 2014.

Secondly, churners also grow debts. Across the twelve years, the median churner's total debt grew from 3.5 to over 4 times the debt of the median ongoing owner. If measured only when churners are in ownership, mean total debt - principally mortgage debt grows from 54\% to 59\% more than that of ongoing owners, and the median churner's debt grows from over 4 to nearly 7 times that of the median ongoing owner. So it could be argued that churning is risky, exposing households to higher levels of debt than they would have incurred had they never dropped out.

A third consideration is that although churning adds substantially to households' assets, by looking at the 33 churning cycles that exactly coincide with HILDA's wealth module years we identify a striking cost in the shape of a narrowing of the wealth portfolio. Nonproperty assets slip from $38 \%$ of total wealth at the end of one ownership spell to $28 \%$ at the beginning of the next. The increased exposure to property is matched by churners winding back secure liquid holdings in bank account balances - average balances fall by nearly one-third from $\$ 35 \mathrm{k}$ to $\$ 24 \mathrm{k}$ - while growing more volatile (risky) business assets and financial investments (the latter rising from a mean of $\$ 23 \mathrm{k}$ to $\$ 32 \mathrm{k}$ ). Superannuation balances (thanks to mandatory contributions) remained roughly constant as a share of all wealth among churners at 15\%. The indication from this small group of churners is that one cost of returning to ownership is a restructuring of asset portfolios to increase the concentration of wealth into housing. To the extent that reentering ownership requires households to draw equity from savings, it adds to that process and thereby to the investment and credit risks this implies ${ }^{11}$.

These added risks might be justified if churning also improved the use and amenity value of housing outcomes, but the evidence is mixed. Although a fair proportion of churners, especially in the USA, add rooms per dwelling, there is also a tendency in all countries to downsize (24\% in Australia, 23\% in the UK, 36\% in the USA). Downsizers are disproportionately older, separated and have lower incomes than upsizers; they found

\footnotetext{
${ }^{11}$ Stafford and Gouskovo (2010) suggest that in the run-up to the GFC, US owners in mortgage distress made similar wealth portfolio adjustments to mitigate their risk of dropping out.
} 
most of the equity needed to return to ownership from the proceeds of their previous sale. They are in some sense classic downsizers with the characteristics of asset-rich, income-poor 'empty nesters' who need less rooms and move down-market to relieve financial distress or service a lifestyle change. Indeed, on downsizing these churners swapped real mean home values of AU\$631k for properties with a mean value of AU $\$ 523 \mathrm{k}$ in Australia, $£ 217 \mathrm{k}$ for $£ 194 \mathrm{k}$ in the UK, and US $\$ 224 \mathrm{k}$ for US\$163k in the USA.

In Australia, it is also possible to observe any locational premium that might be achieved through churning. Churners either shift up, down or sideways across neighbourhoods that have been ranked according to deciles of socio-economic indexes for areas (SEIFA) designed by the Australian Bureau of Statistics to profile neighbourhood socio-economic status. The largest proportion of churners remain in the same neighbourhood or relocate to one with the same status (41-46\%). A smaller proportion improve their location (26$32 \%$ ) but almost as many lose ground (around 28\%). Notably, even among those growing their locational premium or expanding their living space, churning occasions trade-offs that might not improve the property's use value. Across the three SEIFA indices, $22 \%$ to $31 \%$ of those moving to a higher status neighbourhood had to move into a smaller home, and a similar proportion of those adding rooms did so by moving into a lower status neighbourhood.

In short, churners do better financially than lasting leavers, but not, on the whole, as well as ongoing owners. Nor, despite paying more to re-enter the sector than they withdrew when they left, do they necessarily improve their housing position (measured by number of rooms/quality of neighbourhood). In the meantime, churners are more exposed to credit and investment risks than either leavers or ongoing owners, and to greater risks than they themselves carried in their previous ownership spell

\section{Episodic ownership: challenging the status quo?}

For nearly a century, the full weight of governance in the three jurisdictions herein has promoted owner-occupation over renting. Yet, in practice, episodic owner-occupation straddles that tenure divide. In frequency it is not trivial, and as a housing pathway, it marks a break from twentieth century expectations of a linear shift from renting to owning. So whether as an iterative, uncertain, pathway to outright ownership, or an intermittent route to renting, churning seems set to challenge a political imaginary that rests on a binary split. Whether governments going forward lean to the status quo, or embrace the weight of opinion challenging it, they will need to take the expanding edges of ownership into account.

If the aim is business as usual, then arguably the next best thing to preventing households dropping out of ownership is having institutions appropriately arranged to nudge them back in. This is especially important if housing markets are to adjust more efficiently to labour markets (Blanchflower and Oswald, 2013), or respond effectively to relationship breakdown (Clark, 2013b). At the moment, there are initiatives (generally failing) to lever new households into the sector, and measures (relatively successful in the $21^{\text {st }}$ century) to prevent owners dropping out. There is, however, nothing special 
encouraging 'second-time buyers.' This may be risky for the status quo, though it would, of course, be hard to argue that churners are in a weaker position than those who have never owned

Another option is to enlarge the range of rental opportunities to better position churning as a resource. We have shown that the relatively large, diverse US and Australian private rental sectors are effective in easing the friction of churning, while the UK's social sector provides a soft landing for those who need it. However, where rental options are limited, some cling to ownership longer than they should, and drop out with less resources than they need to re-establish their preferred trajectories. So there is an argument for growing the rented sector, though it is a complex challenge, not least because it is already underway, and not especially geared to supporting those at the edges of ownership.

These tactics may not, moreover, fully address the finding that, in all three countries, even the most successful churners face high transactions costs, enhanced credit and investment risks, and uncertain gains, They lose out compared to those who never leave, even though they do better, for the time being, than those who never own, Nor do the 'business as usual' responses tackle the truism that, to the extent that churning is about adjusting housing outlays to stagnating incomes or economic shocks, moving home is an expensive strategy, especially in a market that is contracting as prices rise. At the very least it is worth acknowledging a gap in the personal financial services market to mitigate the risks of temporary rental spells. There have in the past been attempts to design both mortgage instruments and insurance products to this end; the facts of episodic owner-occupation make a strong case for revisiting these.

Critically, however, dropping out of ownership, even for a short time, is a system-wide risk, because, in practice, churning operates selectively for age and for health, sifting and sorting households as they filter from one episode of ownership to the next. This adds 'drop-out' among the old to 'lock-out' for the young as a system-wide hazard, potentially extending existing structural exclusions around age and race (Arundel, 2017, Clark, 2011) to other demographic groups. Such findings should surely stimulate interest in 'less than whole-home' ownership. Surprisingly, this idea has struggled to gain traction, yet, in fractional ownership of myriad kinds, some radical solutions reside. Deliberately creating a space 'between' owning and renting - an altogether new style of home occupation - is what tenure neutrality is about, and it is time to grasp that nettle (Christophers 2019b), not least because, while churners exhibit diverse trajectories, they have one important thing in common: they occupy an underacknowledged, uninstituted space between tenures which can be decisive for their future. So there is latent demand for innovative financial services, unmet needs of all kinds, and untapped potential for radical policy shifts, all adding weight to Adkins et al's (2019) decision to locate churners at the heart of a new social order, shaped by housing experiences.

\section{References}

Adkins, L Cooper, M and Konigns, M (2019) Class in the $21^{\text {st }}$ century. Asset inflation and the new logic of inequality. Environment and Planning $A$ https://doi.org/10.1177/0308518X19873673

Allison PD (2009) Fixed Effects Regression Models: Quantitative Applications in the Social Sciences. California: SAGE 
Arundel R (2017) Equity inequity: housing wealth inequality, inter and intragenerational divergences, and the rise of private landlordism. Housing, Theory and Society 34(2): 176-200.

Arundel R and Ronald R (2020) The false promise of homeownership: Homeowner societies in an era of declining access and rising inequality. Urban Studies online https://doi.org/10.1177/0042098019895227

Berman Y and Milanovic B (2020) Homoploutia: Top Labor and Capital Incomes in the

United States. Stone Centre on Socio-eonomic Inequality Working Paper Series, No. 28.

Blatt R (2012) Home ownership as public policy in the United States. In: Ronald R and Elsinga M (eds) Beyond Homeownership: Housing Welfare and Society. London: Routledge, pp. 130-145.

Blanchflower DG and Oswald AJ (2013) Does Home Ownership Impair the Labour Market, NBER Working Paper Series, Working Paper 19079 http://www.nber.org/papers/w19079

Bridges T and Stafford FP (2012) At the Corner of Main and Wall Street: Family Pension Responses to Liquidity Change and Perceived Returns. Michigan Retirement Research Centre, Working Paper WP 2012-282.

Brien MJ and Sheran ME (2003) The economics of marriage and household formation. In: Grossbard-Schechtman SA (ed) Marriage and the Economy; Theory and Evidence from Advanced Industrial Societies. Cambridge: Cambridge University Press.

Christophers B (2019a) The rentierization of the United Kingdon Economy. Environment and Planning A DOI: 10.1177/0308518X19873007

Christophers B (2019b) A tale of two inequalities. Housing wealth inequality and tenure inequality. Environment and Planning A: Economy and Space. Epub ahead of print 17 September 2019. DOI: 10.1177/0308518X19876946.

Clark WAV (2011) Prices, expectations and the changing housing market: a commentary and discussion. Housing, Theory and Society 28(3): 262-275.

Clark WAV (2013a) Life course events and residential change: unpacking age effects on the probability of moving. Journal of Population Research 30 (4):

Clark WAV (2013b) The aftermath of the general financial crisis for the ownership society: what happened to low-income homeowners in the US?. International Journal of Housing Policy 13(3): 227-246.

Dieleman FM, Clark WAV and Deurloo MC (1995) Falling out of the home owner market. Housing Studies 10(1): 3-15.

Ermisch J and Di Salvo P (1996) Surprises and housing tenure decisions in Great Britain. Journal of Housing Economics 5: 247-273.

Fernandez R and Aalbers MB (2017) Housing and capital in the 21 $1^{\text {st }}$ century: realigning housing studies and political economy Housing, Theory and Society, 34(2): 151-158

Fikse E and Aalbers MB (2020) The really big contradiction: homeownership discourses in times of financialization Housing Studies, DOI: 10.1080/02673037.2020.1784395

Forrest R and Hirayama Y (2018) Late home ownership and social re-stratification. Economy and Society 47(2): 257-279.

Fusco A. and Islam N (2017) Household size and poverty. LISER. Available at: http://www.ecineq.org/ecineq_nyc17/FILESx2017/CR2/p243.pdf (accessed 31 March 2019)

Haffner MEA, Ong R, Smith SJ and Wood GA (2017) The edges of home ownership - the borders of sustainability. International Journal of Housing Policy 17(2): 169-176

Henderson, JV and Ioannides YM (1983) A model of housing tenure choice. The American Economic Review 73: 98-113. 
Henderson, JV and Ioannides YM (1989) Dynamic aspects of consumer decisions in housing markets. Journal of Urban Economics 26: 212-30.

Monk S and Whitehead S (2011) Making Housing More Affordable: The Role of Intermediate Tenures. Oxford: Wiley-Blackwell.

Mikolai, J. and Kulu, H. (2018) Divorce, separation, and housing changes: a multiprocess analysis of longitudinal data from England and Wales. Demography 55: 83-106

Murphy L and Rehm M (2016) Home ownership, asset-based welfare and the actuarial subject. Exploring the dynamics of ageing and homeownership in New Zealand. In: Cook, N, Davison, A and Crabtree, L (eds) Housing and Home Unbound: Intersections in Economics, Environment and Politics in Australia. Oxon: Routledge.

Pawson H Yates J and Milligan V (2019) Housing Policy in Australia: A Case for System Reform. Singapore: Palgrave Macmillan.

Perkins $\mathrm{K}$ (2018) Tenure transitions are more common than we think. https://www.jchs.harvard.edu/blog/tenure-transitions-are-more-common-thanwe-think

Renaud R and Kim K (2007) Global house price boom and its aftermath. Housing Finance International 22: 3-15.

Ronald R (2008) The ideology of home ownership Basingstoke: Palgrave

Ronald R, and Kadi J (2018) The revival of private landlords in Britain's posthomeownership Society, New Political Economy, 23:6, 786-803

Smith SJ (2008). Owner occupation: Living with a hybrid of money and materials. Environment and Planning A, 40: 520-535

Smith SJ (2015) Owner occupation: at home in a spatial, financial paradox. International Journal of Housing Policy 15: 61-83.

Smith SJ and Searle BA (eds) (2010) The economics of housing (part 2) Wiley-Blackwell

Stafford FP and Gouskova E (2010) Mortgage Contract Decisions and Mortgage Distress: Family and Financial Life Cycle Factors. Michigan Retirement Research Centre, Working Paper WP.

Turek K, Kalmijn M and Leopold R (2021) The comparative panel file: harmonized household panel surveys from seven countries. European Sociological Review: 1-19 (doi: $10.1093 /$ esr/jcab006

Watson N and Wooden M (2020) The Household, Income and Labour Dynamics in Australia (HILDA) Survey. Journal of Economics \& Statistics, https://doi.org/10.1515/jbnst-2020-0029

Wood GA, Smith SJ, Ong R and Cigdem M (2013) The Edges of Home Ownership. Final Report No. 216. Melbourne: Australian Housing and Urban Research Institute.

Wood GA and Ong R (2017) The Australian housing system: a quiet revolution? The Australian Economic Review 50(2): 197-204.

Wood GA, Smith SJ, Cigdem M and Ong R (2017) Life on the edge: a perspective on precarious home ownership in Australia and the UK. International Journal of Housing Policy 17(2): 201-226. 
Table 1. Factors affecting the likelihood of return to owner-occupation, 2001-2017

\begin{tabular}{|c|c|c|c|c|c|c|c|c|c|}
\hline \multirow[b]{2}{*}{ Explanatory variables ${ }^{1}$} & \multicolumn{3}{|c|}{ Australia } & \multicolumn{3}{|c|}{ UK } & \multicolumn{3}{|c|}{ USA } \\
\hline & Coeff. & $\begin{array}{l}\text { Std. } \\
\text { error }\end{array}$ & Odds ratio & Coeff. & $\begin{array}{l}\text { Std. } \\
\text { error }\end{array}$ & Odds ratio & Coeff. & $\begin{array}{l}\text { Std. } \\
\text { error }\end{array}$ & Odds ratio \\
\hline LIFE CYCLE (AGE GROUPS) & & & & & & & & & \\
\hline $35-44^{2}$ & -0.0778 & 0.150 & 0.925 & -0.285 & 0.418 & 0.752 & -0.145 & 0.135 & 0.865 \\
\hline $45-54^{2}$ & 0.111 & 0.173 & 1.118 & -0.306 & 0.493 & 0.736 & $-0.419 * * *$ & 0.162 & $0.658^{* * *}$ \\
\hline $55-64^{2}$ & $0.390^{*}$ & 0.204 & $1.476^{*}$ & -0.391 & 0.573 & 0.676 & $-0.322^{*}$ & 0.193 & $0.725^{*}$ \\
\hline$\geq 65^{2}$ & -0.265 & 0.237 & 0.767 & $-1.476^{* *}$ & 0.631 & $0.229 * *$ & $-0.965^{* * *}$ & 0.254 & $0.381^{* * *}$ \\
\hline HOUSEHOLD STRUCTURE & & & & & & & & & \\
\hline De facto (partnership) & -0.169 & 0.162 & 0.844 & 0.826 & 0.512 & 2.285 & $-0.622^{* * *}$ & 0.218 & $0.537^{* * *}$ \\
\hline Separated/Divorced & $-0.371^{* * *}$ & 0.143 & $0.690 * * *$ & $0.858^{* *}$ & 0.407 & $2.359 * *$ & $-0.579 * * *$ & 0.124 & $0.561^{* * *}$ \\
\hline Widowed & -0.197 & 0.223 & 0.821 & 0.394 & 0.562 & 1.482 & $-0.491^{*}$ & 0.291 & $0.612^{*}$ \\
\hline Single/Never married & $-0.578^{* * *}$ & 0.196 & $0.561^{* * *}$ & $0.752^{*}$ & 0.44 & $2.122 *$ & $-1.008^{* * *}$ & 0.208 & $0.365^{* * *}$ \\
\hline Loss partner while renting & $-0.871^{* * *}$ & 0.135 & $0.419^{* * *}$ & $-1.008^{* * *}$ & 0.353 & $0.365^{* * *}$ & $-1.058^{* * *}$ & 0.19 & $0.347^{* * *}$ \\
\hline Dependent children present & $0.301^{* *}$ & 0.130 & $1.351^{* *}$ & -0.160 & 0.391 & 0.852 & $-0.213^{*}$ & 0.125 & $0.808^{*}$ \\
\hline $\begin{array}{l}\text { Dependent child added while renting } \\
\text { HEALTH, WEALTH \& INCOME }\end{array}$ & $-0.478^{* * *}$ & 0.140 & $0.620^{* * *}$ & $-0.830^{*}$ & 0.486 & $0.436^{*}$ & -0.181 & 0.138 & 0.834 \\
\hline Fair to poor health & $-0.429^{* * *}$ & 0.124 & $0.651^{* * *}$ & -0.372 & 0.296 & 0.690 & $-0.244^{*}$ & 0.143 & $0.783^{*}$ \\
\hline Tertiary qualification & $0.305^{* *}$ & 0.124 & $1.357^{* *}$ & $0.957^{* *}$ & 0.382 & $2.604^{* *}$ & $0.393^{* * *}$ & 0.113 & $1.481^{* * *}$ \\
\hline Employed & $0.378^{* * *}$ & 0.128 & $1.459^{* * *}$ & 0.565 & 0.359 & 1.759 & $0.314^{* *}$ & 0.128 & $1.369 * *$ \\
\hline Loss employment while renting & $-1.113^{* * *}$ & 0.130 & $0.329 * * *$ & $-1.011^{* * *}$ & 0.392 & $0.364^{* * *}$ & $-0.978^{* * *}$ & 0.141 & $0.376^{* * *}$ \\
\hline $\begin{array}{l}\text { User cost from last observation in } \\
\text { ownership }\end{array}$ & -0.0250 & 0.0558 & 0.975 & $-0.734^{* * *}$ & 0.19 & $0.480^{* * *}$ & -0.124 & 0.0952 & 0.883 \\
\hline $\begin{array}{l}\text { Real amount of equity released upon } \\
\text { selling up (AU } \$ / £ / U S \$ 00,000)\end{array}$ & $0.0523^{* * *}$ & 0.0145 & $1.054^{* * *}$ & 0.175 & 0.138 & 1.191 & $0.108^{* * *}$ & 0.0364 & $1.114^{* * *}$ \\
\hline $\begin{array}{l}\text { Received inheritance in last financial } \\
\text { year }{ }^{3}\end{array}$ & 0.559 & 0.346 & 1.748 & & & & $1.096^{* *}$ & 0.429 & $2.992^{* *}$ \\
\hline $\begin{array}{l}\text { Received parental gift } \geq A U \$ 5,000 \text { in last } \\
\text { financial year }{ }^{3} \\
\text { HOUSING }\end{array}$ & 0.136 & 0.517 & 1.146 & & & & & & \\
\hline Social housing & $-1.047^{* * *}$ & 0.275 & $0.351^{* * *}$ & $-1.453^{* * *}$ & 0.447 & $0.234^{* * *}$ & -0.00576 & 0.296 & 0.994 \\
\hline Rent-free & $0.312^{* * *}$ & 0.116 & $1.366^{* * *}$ & 0.433 & 0.314 & 1.542 & $0.331^{* *}$ & 0.13 & $1.392^{* *}$ \\
\hline ETHNICITY & & & & & & & & & \\
\hline $\begin{array}{l}\text { Aus: Mainly English-speaking countries } \\
\text { other than Australia } 4\end{array}$ & 0.196 & 0.178 & 1.216 & & & & & & \\
\hline Aus: Other ${ }^{4}$ & $-0.348^{*}$ & 0.186 & $0.706^{*}$ & & & & & & \\
\hline UK: Black, Asian and other & & & & $1.814^{* *}$ & 0.875 & $6.136^{* *}$ & & & \\
\hline
\end{tabular}




\begin{tabular}{|c|c|c|c|c|c|c|c|c|c|}
\hline \multirow[b]{2}{*}{ Explanatory variables ${ }^{1}$} & \multicolumn{3}{|c|}{ Australia } & \multicolumn{3}{|c|}{ UK } & \multicolumn{3}{|c|}{ USA } \\
\hline & Coeff. & $\begin{array}{l}\text { Std. } \\
\text { error }\end{array}$ & Odds ratio & Coeff. & $\begin{array}{l}\text { Std. } \\
\text { error }\end{array}$ & Odds ratio & Coeff. & $\begin{array}{l}\text { Std. } \\
\text { error }\end{array}$ & Odds ratio \\
\hline $\begin{array}{l}\text { USA: Black } \\
\text { USA: Other } \\
\text { Constant } \\
\text { Year fixed effects } 5 \\
\text { Region }^{5}\end{array}$ & -0.0834 & $\begin{array}{l}0.393 \\
\text { Include } \\
\text { Include }\end{array}$ & 0.920 & $4.426^{* * *}$ & $\begin{array}{l}1.283 \\
\text { Include } \\
\text { Include }\end{array}$ & $83.59^{* * *}$ & $\begin{array}{l}0.0568 \\
0.332 \\
0.355\end{array}$ & $\begin{array}{c}0.189 \\
0.25 \\
0.514 \\
\text { Includ } \\
\text { Include }\end{array}$ & $\begin{array}{l}1.058 \\
1.393 \\
1.426\end{array}$ \\
\hline $\begin{array}{l}\text { Observations } \\
\text { Wald-chi }{ }^{2} \\
\text { LR test of rho }=0\end{array}$ & & $\begin{array}{r}5,510 \\
371.07^{* *} \\
147.02^{* *}\end{array}$ & & & $\begin{array}{r}1,424 \\
106.57^{* *} \\
17.86^{* *}\end{array}$ & & & $\begin{array}{r}2,936 \\
241.30^{*} \\
1.86^{*}\end{array}$ & \\
\hline
\end{tabular}

Source: Authors' calculations from 2001-2017 HILDA, 2001-2008 BHPS, 2010-2017 UKHLS, 2001-2017 PSID

Notes: significant at $1 \%$ level***, $5 \%$ ** and $10 \% *$ levels.

${ }^{1}$ The reference categories are:

- All countries: $<35$ years old, married, did not lose a partner while renting, no dependent children, did not have additional dependent children while renting, good-to-excellent health, no tertiary education, not employed, did not lose employment while renting, did not receive inheritance in the last financial year, did not receive inheritance, did not receive a parental gift of $\geq A U \$ 5000$, private renters;

- $\quad$ Region and Time fixed effects:

- Australia: Born in Australia, Greater Sydney, 2002;

- UK: white British, South East region, 2002;

USA: white, South Atlantic region, 2003.

${ }^{2}$ Age is categorised to capture life cycle effects and avoid collinearity with year fixed effects; continuous age does not, however, greatly affect the results.

3Inheritance and parental gifts data are unavailable in some surveys.

${ }^{4}$ For Australia, the ethnicity variable reflects place of birth.

${ }^{5}$ Refer to full results in Tables S4-S6 for further details on year and region. 
Table 2. Mean housing wealth on selling up and returning to home ownership, 2001-2017, in 2017 currency values ('000)

\begin{tabular}{|c|c|c|c|c|c|c|c|c|c|}
\hline & \multicolumn{3}{|c|}{ Australia (AU\$) } & \multicolumn{3}{|c|}{ UK $(£)$} & \multicolumn{3}{|c|}{ USA (US\$) } \\
\hline & $\begin{array}{c}\text { Housing } \\
\text { equity }\end{array}$ & $\begin{array}{c}\text { Mortgage } \\
\text { debt }\end{array}$ & $\begin{array}{l}\text { House } \\
\text { value }\end{array}$ & $\begin{array}{c}\text { Housing } \\
\text { equity }\end{array}$ & $\begin{array}{c}\text { Mortgage } \\
\text { debt }\end{array}$ & $\begin{array}{c}\text { House } \\
\text { value }\end{array}$ & $\begin{array}{c}\text { Housing } \\
\text { equity }\end{array}$ & $\begin{array}{c}\text { Mortgage } \\
\text { debt }\end{array}$ & $\begin{array}{l}\text { House } \\
\text { value }\end{array}$ \\
\hline Last wave of previous spell & 379.2 & 152.7 & 531.9 & 165.9 & 50.8 & 216.7 & 95.6 & 143.1 & 238.7 \\
\hline First wave of next spell & 390.3 & 205.8 & 596.0 & 170.6 & 69.7 & 240.3 & 113.1 & 153.2 & 266.4 \\
\hline Difference & 11.1 & 53.0 & 64.1 & 4.7 & 18.9 & 23.5 & 17.5 & 10.1 & 27.7 \\
\hline Number of spells & 1317 & 1317 & 1317 & 257 & 257 & 257 & 694 & 694 & 694 \\
\hline
\end{tabular}

Source: Authors' calculations from 2001-2017 HILDA, 2001-2008 BHPS, 2010-2017 UKHLS, 2001-2017 PSID

Notes: The unit of analysis is spells. 
Table 3. Total household assets and debts by housing trajectory for Australia, 2002-2014, in 2017 currency values (AU\$”000)

\begin{tabular}{|c|c|c|c|c|c|c|}
\hline & \multicolumn{2}{|c|}{ Churners } & \multicolumn{2}{|c|}{ Lasting leavers } & \multicolumn{2}{|c|}{ Ongoing Owners } \\
\hline & Assets & Debts & Assets & Debts & Assets & Debts \\
\hline \multicolumn{7}{|l|}{ Mean } \\
\hline 2002 & 852.4 & 160.0 & 567.6 & 87.2 & 927.3 & 114.2 \\
\hline 2006 & 1197.2 & 233.9 & 701.2 & 130.6 & 1280.7 & 154.8 \\
\hline 2010 & 1265.8 & 281.5 & 690.4 & 147.7 & 1397.6 & 178.6 \\
\hline 2014 & 1325.9 & 260.4 & 662.3 & 136.6 & 1488.4 & 182.3 \\
\hline \multicolumn{7}{|l|}{ Median } \\
\hline 2002 & 496.3 & 79.4 & 346.8 & 18.1 & 619.3 & 22.6 \\
\hline 2006 & 740.1 & 116.5 & 475.5 & 13.0 & 864.2 & 33.6 \\
\hline 2010 & 833.4 & 144.6 & 412.4 & 18.3 & 954.7 & 34.7 \\
\hline 2014 & 860.5 & 112.9 & 322.4 & 7.9 & 1043.9 & 26.6 \\
\hline Count & \multicolumn{2}{|c|}{1159} & \multicolumn{2}{|c|}{516} & \multicolumn{2}{|c|}{4167} \\
\hline
\end{tabular}

Source: Authors' calculations using 2002, 2006, 2010, and 2014 HILDA Survey

Notes: The unit of analysis is spells. 
Table A1. Time-varying characteristics of those who returned to home ownership versus those who remained as renters; 2001-2017 person-year observations, percent by column unless stated otherwise

\begin{tabular}{|c|c|c|c|c|c|c|c|c|c|}
\hline \multirow[t]{3}{*}{ Characteristics in previous wave ${ }^{1}$} & \multicolumn{9}{|c|}{ Whether returned to ownership in present wave ${ }^{1}$} \\
\hline & \multicolumn{3}{|c|}{ Australia } & \multicolumn{3}{|c|}{ UK } & \multicolumn{3}{|c|}{ USA } \\
\hline & No & Yes & All & No & Yes & All & No & Yes & All \\
\hline Mean age (years) & 51.1 & 49.1 & 50.7 & 53.6 & 48.1 & 52.9 & 47.0 & 44.1 & 46.3 \\
\hline$<35$ & $13.4 \%$ & $16.5 \%$ & $14.0 \%$ & $13.8 \%$ & $22.5 \%$ & $14.9 \%$ & $23.3 \%$ & $27.7 \%$ & $24.4 \%$ \\
\hline $35-44$ & $25.9 \%$ & $27.2 \%$ & $26.2 \%$ & $23.6 \%$ & $26.4 \%$ & $24.0 \%$ & $29.2 \%$ & $32.0 \%$ & $29.9 \%$ \\
\hline $45-54$ & $24.4 \%$ & $22.9 \%$ & $24.1 \%$ & $20.3 \%$ & $21.3 \%$ & $20.5 \%$ & $19.3 \%$ & $19.4 \%$ & $19.3 \%$ \\
\hline $55-64$ & $15.6 \%$ & $17.9 \%$ & $16.1 \%$ & $12.3 \%$ & $12.9 \%$ & $12.4 \%$ & $14.5 \%$ & $13.9 \%$ & $14.4 \%$ \\
\hline \multicolumn{10}{|l|}{ Marital Status } \\
\hline Married & $37.9 \%$ & $52.2 \%$ & $40.9 \%$ & $38.1 \%$ & $33.7 \%$ & $37.6 \%$ & $41.7 \%$ & $58.9 \%$ & $45.9 \%$ \\
\hline De facto & $12.7 \%$ & $12.8 \%$ & $12.7 \%$ & $11.2 \%$ & $11.8 \%$ & $11.3 \%$ & $8.7 \%$ & $5.3 \%$ & $7.9 \%$ \\
\hline Separated/Divorced & $30.3 \%$ & $21.1 \%$ & $28.3 \%$ & $22.9 \%$ & $24.7 \%$ & $23.1 \%$ & $33.5 \%$ & $25.5 \%$ & $31.5 \%$ \\
\hline Widowed & $8.4 \%$ & $5.9 \%$ & $7.9 \%$ & $13.7 \%$ & $7.3 \%$ & $12.9 \%$ & $6.2 \%$ & $3.2 \%$ & $5.4 \%$ \\
\hline Single/Never married & $10.8 \%$ & $8.0 \%$ & $10.2 \%$ & $13.9 \%$ & $21.9 \%$ & $14.9 \%$ & $10.0 \%$ & $7.2 \%$ & $9.3 \%$ \\
\hline Dependent children present & $32.3 \%$ & $39.6 \%$ & $33.8 \%$ & $28.6 \%$ & $26.4 \%$ & $28.3 \%$ & $42.8 \%$ & $48.2 \%$ & $44.1 \%$ \\
\hline Highest qualification is tertiary & $21.2 \%$ & $28.3 \%$ & $22.7 \%$ & $10.5 \%$ & $27.5 \%$ & $12.6 \%$ & $29.5 \%$ & $43.4 \%$ & $32.8 \%$ \\
\hline \multicolumn{10}{|l|}{ Health status } \\
\hline Good to excellent & $75.1 \%$ & $84.2 \%$ & $77.0 \%$ & $65.2 \%$ & $70.8 \%$ & $65.9 \%$ & $77.2 \%$ & $85.9 \%$ & $79.3 \%$ \\
\hline \multicolumn{10}{|l|}{ Employment status } \\
\hline Employed & $56.7 \%$ & $69.9 \%$ & $59.5 \%$ & $48.0 \%$ & $66.3 \%$ & $50.3 \%$ & $62.1 \%$ & $74.2 \%$ & $65.0 \%$ \\
\hline \multicolumn{10}{|l|}{ Gift/Inheritance ${ }^{1}$} \\
\hline Inheritance recipient & $1.1 \%$ & $1.8 \%$ & $1.3 \%$ & & & & $0.8 \%$ & $1.8 \%$ & $1.0 \%$ \\
\hline $\begin{array}{l}\text { Inheritance amount, } \\
\text { recipients only (AU\$ } 000)\end{array}$ & 74.9 & 93.8 & 80.5 & & & & & & \\
\hline Parental gift recipients & $2.2 \%$ & $1.5 \%$ & $2.1 \%$ & & & & & & \\
\hline $\begin{array}{l}\text { Parental gift amount, } \\
\text { recipients only (AU\$'000) }\end{array}$ & 7.8 & 18.7 & 9.6 & & & & & & \\
\hline \multicolumn{10}{|l|}{ Renter type } \\
\hline Private & $70.1 \%$ & $69.0 \%$ & $69.8 \%$ & $41.2 \%$ & $53.4 \%$ & $42.7 \%$ & $78.6 \%$ & $77.6 \%$ & $78.3 \%$ \\
\hline Social & $7.1 \%$ & $2.3 \%$ & $6.0 \%$ & $32.2 \%$ & $7.3 \%$ & $29.1 \%$ & $4.3 \%$ & $2.5 \%$ & $3.9 \%$ \\
\hline Rent-free & $22.9 \%$ & $28.7 \%$ & $24.1 \%$ & $26.7 \%$ & $39.3 \%$ & $28.2 \%$ & $17.1 \%$ & $19.9 \%$ & $17.8 \%$ \\
\hline Sample & 4,333 & 1,178 & 5,511 & 1249 & 178 & 1,427 & 2,241 & 722 & 2,963 \\
\hline
\end{tabular}

Source: Authors' calculations from 2001-2017 HILDA, 2001-2008 BHPS, 2010-2017 UKHLS, 2001-2017 PSID 
Notes:

${ }^{1}$ Data on inheritance and parental gifts are unavailable in some surveys.

Table A2. Fixed characteristics of those who returned to home ownership versus those who remained as renters; $2001-2017$ spell observations, percent by column unless stated otherwise

\begin{tabular}{|c|c|c|c|c|c|c|c|c|c|}
\hline \multirow[b]{3}{*}{$\begin{array}{l}\text { Characteristics in latest rental spell or } \\
\text { previous ownership spell }\end{array}$} & \multicolumn{9}{|c|}{ Whether returned to ownership in present spell } \\
\hline & \multicolumn{3}{|c|}{ Australia } & \multicolumn{3}{|c|}{ UK } & \multicolumn{3}{|c|}{ USA } \\
\hline & No & Yes & All & No & Yes & All & No & Yes & All \\
\hline Lost partner while renting & $30.9 \%$ & $17.1 \%$ & $21.6 \%$ & $26.1 \%$ & $23.6 \%$ & $24.9 \%$ & $15.1 \%$ & $6.6 \%$ & $10.2 \%$ \\
\hline Had additional children while renting & $16.2 \%$ & $18.5 \%$ & $17.8 \%$ & $13.0 \%$ & $11.8 \%$ & $12.4 \%$ & $15.5 \%$ & $18.4 \%$ & $17.2 \%$ \\
\hline Lost employment while renting & $26.8 \%$ & $16.8 \%$ & $20.1 \%$ & $21.7 \%$ & $15.7 \%$ & $18.8 \%$ & $24.3 \%$ & $13.9 \%$ & $18.3 \%$ \\
\hline $\begin{array}{l}\text { Mean user cost from last observation in } \\
\text { ownership }\end{array}$ & $4.3 \%$ & $4.3 \%$ & $4.3 \%$ & $3.9 \%$ & $4.0 \%$ & $4.0 \%$ & $2.9 \%$ & $3.2 \%$ & $3.1 \%$ \\
\hline $\begin{array}{l}\text { Mean real amount of equity released upon } \\
\text { selling up in } 2017 \text { currency values ('000) }\end{array}$ & AU\$289.9 & AU $\$ 374.8$ & AU\$347.2 & $£ 122.4$ & $£ 149.0$ & $£ 135.5$ & US\$78.3 & US\$91.0 & US\$85.6 \\
\hline
\end{tabular}

Source: Authors' calculations using the 2001-2017 HILDA, 2001-2008 BHPS, 2010-2017 UKHLS, 2001-2017 PSID 


\section{SUPPLEMENTARY MATERIAL}

This supplementary material provides details on the sample design and variable definitions employed in our modelling exercises. It also describes key features of each of the three panel surveys, including measures taken in order to address attrition. Finally, we present additional descriptive statistics and model estimates that help to justify interpretation of various results that are discussed in the main text.

\section{Unit of analysis: person-years or episodes}

As reported in the main text, the sample design results in an unbalanced panel of respondents comprising 5,885 Australian, 4,270 British and 5,836 American individuals. From the unbalanced panel, we created person-years by stacking observations from the selected individuals within a long file. Person-year observations (episodes) belonging to rental spells (in either private renting, social housing or rent-free) after any loss of home ownership were kept in the long file. The sample design ensures that each rental episode belongs to a rental spell whose onset is preceded by an exit from home ownership. Each rental episode at wave $t$ is then matched to a tenure episode at $t+1$ to determine whether a re-entry into home ownership was achieved at $t+1$.

\section{Comparability of the four surveys}

While there are differences across large-scale datasets as complex as these, the four surveys have important similarities in their design. Indeed, the HILDA Survey design and content was specifically based on other household panel surveys including the BHPS (Watson and Wooden, 2020). We provide further details on the four surveys below, documenting their similarities while also highlighting differences pertinent to the paper's analysis. But first we note that these surveys have already been used successfully for crossnational research purposes. For instance, Smith et al. (2017) used HILDA and BHPS to study cross-country comparisons of the links between home ownership and wellbeing; Mendolia and Siminski (2016) use HILDA and PSID to study intergenerational mobility; while Booth and Katic (2011) model wage elasticities using HILDA, BHPS and PSID.

\section{Survey tracking rules}

The four surveys have similar rules defining individuals that possess the so-called survey 'gene' and therefore continue to be tracked from wave to wave, regardless of biographical disruptions (e.g., divorce) that change the composition and number of households. These rules assign the survey 'gene' to:

- Persons included in wave 1 of the survey.

- Children subsequently born to or adopted by adults with the survey 'gene'. 
- Persons subsequently joining a household after wave 1 , who have a child with a person possessing the survey 'gene' (in the case of HILDA'12, BHPS and UKHLS, but not PSID).

Persons who do not fit into any of these three categories are classified as temporary sample members and are only followed while they share a household with a person that has the survey 'gene'.

\section{Attrition}

Attrition afflicts all panel survey, however the record of each sample country's survey is relatively good ${ }^{13}$, and reflects rigorous panel maintenance strategies that include maintaining interviewer-respondent continuity (Watson et. al., 2019) and incentive payments (McGonagle et. al., 2012). The effects of attrition on sample size and representativeness are also mitigated in two other ways. Firstly, sample size is preserved because the panel is continually replenished over time through the recruitment of children born to existing sample members. Secondly, in all the surveys, new respondents have been added to the wave 1 sample as refresher or booster samples to address attrition, maintain representativeness, and in particular to account for immigrant arrivals since the commencement of each survey. The booster respondents are tracked as continuing survey participants with the survey 'gene'.

\subsection{HILDA booster samples}

In the HILDA Survey, a general top-up sample of around 2,000 responding households were added to the 2011 sample to allow for representation of post-2001 immigrants who became permanent residents, long-term visitors and overseas returning Australians, as well as Australian-born children of these groups (Watson 2011).

\subsection{BHPS and UKHLS booster samples}

In 1999, the BHPS added a top-up sample of 1,500 households from Scotland and 1,500 households from Wales to the 1991 sample of 5,000 households. In 2000, 2,000 households from Northern Ireland were added. The UKHLS began between 2009-2010 with a General Population Sample of 26,000 households drawn from across the UK. In wave 2 (20102011), approximately 8,000 households who had participated in BHPS were added 14 ;

12 In HILDA there is an exception to this. From wave 9, new household members who were immigrants arriving in Australia for the first time after 2001 were also added to the sample on a continuing basis. In wave 16 this rule was amended (given the refresher sample added in 2011) to only cover immigrants arriving after 2011 (Watson and Wooden, 2020).

${ }_{13}$ PSID is outstanding reporting annual re-interview rates in excess of $97 \%$ for most of its life (Watson et. al., 2019). Wave by wave re-interview rates have been steadily increasing in HILDA reaching over $96 \%$ from wave 9 onwards (Watson and Wooden, 2020). PSID and HILDA come first and second among a sample of 7 panel surveys compared in Watson et al (2019, figure 29.1).

${ }^{14}$ As this is a subset of the BHPS panel that completed the final wave of BHPS in 2008 tracking all BHPS participants over the entire observation period is impossible, and there is a sharp spike in attrition between 2008 and the re-commencement of interviews over the years 2010 and 2011. In the last wave of BHPS (2008) 
roughly 4,000 extra households from the Ethnic Minority Boost Sample (EMBS) were also included in wave 2. Finally, another 2,900 households of the Immigration and Ethnicity boost sample were added in 2015 (Institute for Social and Economic Research, 2020).

\subsection{PSID booster samples}

In the PSID, booster samples were added to increase the representation of immigrants arriving in the USA after 1968. These booster samples were included in 1997 and 1999 prior to the start of our study timeframe in 2001 (Institute for Social Research 2015b).

\section{Interview frequencies}

We draw on the 2001-2017 HILDA Survey and the 2001-2017 PSID. In the UK data BHPS was discontinued after 2008. We employ the 2001-2008 BHPS and surviving 8,000 BHPS households that were retained in the larger sample frame of its successor the UKHLS over the period 2009-2017.

The HILDA Survey, BHPS and UKHLS interviews respondents annually. Hence, Australian and UK transitions back to home ownership are measured between $t$ and $t+1$. The PSID was historically rolled out annually, but since 1997 interviews have been conducted biannually so over the timeframe covered in this paper PSID transitions back to home ownership are measured between $t$ and $t+2^{15}$.

The UKHLS has two features not shared by the other surveys that complicate transition analysis of the kind we conduct. First, while each respondent's UKHLS interviews are conducted at one-year intervals, the entire survey is rolled out over a two-year window. So, for instance, wave 2 of the UKHLS extended over 2010-2011, wave 3 over 2011-2012 etc. This results in some overlapping timelines across UKHLS waves ${ }^{16}$. Second, the BHPS ended in 2008, but BHPS respondents were not re-interviewed in the UKHLS till its second wave (2010). There is then a two-year gap between the final wave of BHPS (2008) and BHPS respondents' first interviews in the UKHLS ${ }^{17}$. This in turn means that renters' prospects of re-entry into home ownership in 2008 are typically measured between $t$ and $t+2$, while in all other waves they are measured between $t$ and $t+1$.

\footnotetext{
16,747 respondents reported a housing tenure status and were subsequently interviewed in one or more of UKHLS from 2010 onwards. There were 3572 individuals interviewed in the last wave of BHPS who reported a housing tenure status but were not subsequently interviewed in UKHLS and therefore attrited. They are $18 \%$ of the 20,319 BHPS survey participants who reported a housing tenure status is the last wave of BHPS. 15 Hence the estimated odds ratios for year fixed effects are higher in the USA model than comparable estimates of year fixed effects odds ratios in the other two countries (see Section IV below).

16 This means that one respondent i might have wave 1 and wave 2 interviews in 2009 and 2010, while another respondent $\mathrm{j}$ has wave 1 and 2 interviews conducted in 2010 and 2011. Respondent i's wave 2 interview is then completed in the same calendar year as j's wave 1 interview.

${ }_{17}$ And since some wave 2 interviews were conducted in 2011 there is a 3 year gap for some BHPS respondents.
} 


\section{References for further survey details}

Readers interested in further survey details can refer to the following literature from the survey organizations.

\subsection{HILDA}

- Melbourne Institute of Applied Economic and Social Research (2018), Release 17 Subject Level Coding Framework: General Release. Melbourne Institute: Applied Economic and Social Research, University of Melbourne. Retrieved from https://dataverse.ada.edu.au/dataverse/hilda

- $\quad$ Summerfield, M., Bevitt, A., Fok, Y., Hahn, M., La, N., Macalalad, N., O’Shea, M., Watson, N., Wilkins, R. and Wooden, M. (2018), HILDA User Manual - Release 17'. Melbourne Institute: Applied Economic and Social Research, University of Melbourne. Retrieved from https://melbourneinstitute.unimelb.edu.au/_data/assets/pdf_file/0004/2939053/HILDA-User-ManualRelease-17.1.pdf

- Watson, N. (2011), Methodology for the HILDA top-up. HILDA Project Technical Paper Series No. 1/11, September. Melbourne Institute of Applied Economic and Social Research, University of Melbourne. Retrieved from https://melbourneinstitute.unimelb.edu.au/assets/documents/hilda-bibliography/hildatechnical-papers/htec111.pdf

- $\quad$ Watson, N. and Wooden, M., The Household, Income and Labour Dynamics in Australia (HILDA) Survey, Jahrbücher für Nationalökonomie und Statistik (Journal of Economics and Statistics). DOI: https://doi.org/10.1515/jbnst-2020-0029

\subsection{BHPS and UKHLS}

- Institute for Social and Economic Research. (2020). Understanding Society: Waves 1-10, 2009-2019 and Harmonised BHPS: Waves 1-18, 1991-2009, User Guide, 29 October 2020. Colchester: University of Essex . Retrieved from https://www.understandingsociety.ac.uk/sites/default/files/downloads/documentation/mainstage/us er-guides/bhps-harmonised-user-guide.pdf

\subsection{PSID}

- Institute for Social Research. (2017). Panel Study of Income Dynamics: 2017 Public Release Family File Codebook. Ann Arbor, Michigan: Institute for Social Research, University of Michigan. Retrieved from ftp://ftp.isr.umich.edu/pub/src/psid/codebook/FAM2017ER codebook.pdf

- Institute for Social Research. (2019). PSID Main Interview User Manual: Release 2019. Institute for Social Research, University of Michigan. Retrieved from https://psidonline.isr.umich.edu/data/Documentation/UserGuide2017.pdf

- Institute for Social Research. (2020). Panel Study of Income Dynamics, Public Use Dataset. Produced and distributed by the Survey Research Center, Ann Arbor, Michigan: Institute for Social Research, University of Michigan. Retrieved from http://psidonline.isr.umich.edu

- $\quad$ McGonagle, K., Schoeni, R., Sastry, N., \& Freedman, V. A. (2012). The Panel Study of Income Dynamics: Overview, recent innovations, and potential for life course research. Longitudinal and Life Course Studies, 3(2), 268-284. https://doi.org/10.14301/llcs.v3i2.188

\section{Model explanatory variables}

The model specification includes a range of socio-demographic, human capital and housing factors that are likely to affect tenure transitions. In particular, we focus on variables that allow us to study the effects of biographical shifts, financial shocks, and other life events on housing transitions. 
The variables can be broadly classified into time-varying variables, that can change in value across episodes of a rental spell following loss of home ownership, and spellinvariant variables, that is variables that can take only one value across episodes of those same rental spells.

\section{Time-varying variables}

Table S1 defines each time-varying variable, and identifies categorical variables where the coding of categories differs across countries.

Table S1: Time-varying variables in the models

\begin{tabular}{|c|c|c|}
\hline Variable name & Variable definitions & Country exceptions \\
\hline Age and age $2 / 100$ & Continuous age and its square & \\
\hline $\begin{array}{l}<35 \text { years old (omitted) } \\
35-44 \text { years old } \\
45-54 \text { years old } \\
55-64 \text { years old } \\
65 \text { years and above } \\
\end{array}$ & $\begin{array}{l}1 \text { if aged }<35 \text { years old; } 0 \text { otherwise } \\
1 \text { if aged } 35-44 \text { years old; } 0 \text { otherwise } \\
1 \text { if aged } 45-54 \text { years old; } 0 \text { otherwise } \\
1 \text { if aged } 55-64 \text { years old; } 0 \text { otherwise } \\
1 \text { if aged } 65+\text { years old; } 0 \text { otherwise }\end{array}$ & \\
\hline $\begin{array}{l}\text { Legally married (omitted) } \\
\text { De facto } \\
\text { Separated/Divorced } \\
\text { Widowed } \\
\text { Single/Never married }\end{array}$ & $\begin{array}{l}1 \text { if legally married; } 0 \text { otherwise } \\
1 \text { if de facto (cohabiting); } 0 \text { otherwise } \\
1 \text { if separated or divorced; } 0 \text { otherwise } \\
1 \text { if widowed; } 0 \text { otherwise } \\
1 \text { if single never married; } 0 \text { otherwise }\end{array}$ & \\
\hline Dependent children present & $\begin{array}{l}1 \text { if number of dependent children exceed } \\
\text { zero; } 0 \text { if has no dependent children }\end{array}$ & \\
\hline Fair to poor health & $\begin{array}{l}1 \text { if health is fair to poor; } 0 \text { if health is better } \\
\text { than fair }\end{array}$ & $\begin{array}{l}\text { BHPS/UKHLS: } 1 \text { if health is } \\
\text { fair to very poor; } 0 \text { if health is } \\
\text { better than fair. }\end{array}$ \\
\hline $\begin{array}{l}\text { Highest qualification is } \\
\text { tertiary }\end{array}$ & $\begin{array}{l}1 \text { if highest qualification is a university } \\
\text { degree; } 0 \text { otherwise }\end{array}$ & $\begin{array}{l}\text { PSID: } 1 \text { if received a college } \\
\text { degree. }\end{array}$ \\
\hline Employed & 1 if employed; 0 otherwise & \\
\hline Received inheritance & $\begin{array}{l}1 \text { if received an inheritance (bequest) in the } \\
\text { last financial year); } 0 \text { otherwise }\end{array}$ & $\begin{array}{l}\text { Not available in the UKHLS. } \\
\text { Variable is therefore excluded } \\
\text { from the UK model. }\end{array}$ \\
\hline $\begin{array}{l}\text { Received parental } \\
\text { gift/transfer of } \\
>=\text { AU } \$ 5000\end{array}$ & $\begin{array}{l}1 \text { if received a monetary transfer of } \\
>=A U \$ 5000 \text { from parents while parents still } \\
\text { alive in the last financial year; } 0 \text { otherwise. }\end{array}$ & $\begin{array}{l}\text { Not available in the BHPS, } \\
\text { UKHLS and PSID. Variable is } \\
\text { therefore excluded from the } \\
\text { UK and USA models. }\end{array}$ \\
\hline $\begin{array}{l}\text { Social housing } \\
\text { Rent-free housing } \\
\text { Private rental (omitted) } \\
\end{array}$ & $\begin{array}{l}1 \text { if living in public housing or community } \\
\text { housing; } 0 \text { otherwise. } \\
1 \text { if not home owner and not paying rent; } 0 \\
\text { otherwise. } \\
1 \text { if private renter; } 0 \text { otherwise. }\end{array}$ & \\
\hline $\begin{array}{l}2001 \\
2002 \\
2003 \\
2004 \\
2005 \\
2006 \\
2007 \\
2008\end{array}$ & $\begin{array}{l}1 \text { if observation is from 2001; } 0 \text { otherwise } \\
1 \text { if observation from 2002; } 0 \text { otherwise } \\
1 \text { if observation is from 2003; } 0 \text { otherwise } \\
1 \text { if observation from 2004; } 0 \text { otherwise } \\
1 \text { if observation is from 2005; } 0 \text { otherwise } \\
1 \text { if observation from 2006; } 0 \text { otherwise } \\
1 \text { if observation is from 2007; } 0 \text { otherwise } \\
1 \text { if observation from } 2008 ; 0 \text { otherwise }\end{array}$ & $\begin{array}{l}\text { No PSID observation } \\
\text { No PSID observation } \\
\text { No PSID observation } \\
\text { No PSID observation }\end{array}$ \\
\hline
\end{tabular}




\begin{tabular}{|c|c|c|}
\hline Variable name & Variable definitions & Country exceptions \\
\hline $\begin{array}{l}2009 \\
2010 \\
2011 \\
2012 \\
2013 \\
2014 \\
2015 \\
2016 \\
2017 \\
\end{array}$ & $\begin{array}{l}1 \text { if observation is from 2009; } 0 \text { otherwise } \\
1 \text { if observation from 2010; } 0 \text { otherwise } \\
1 \text { if observation is from 2011; } 0 \text { otherwise } \\
1 \text { if observation from 2012; } 0 \text { otherwise } \\
1 \text { if observation is from 2013; } 0 \text { otherwise } \\
1 \text { if observation from 2014; } 0 \text { otherwise } \\
1 \text { if observation is from 2015; } 0 \text { otherwise } \\
1 \text { if observation from 2016; } 0 \text { otherwise } \\
1 \text { if observation from 2017;0 otherwise }\end{array}$ & $\begin{array}{l}\text { No BHPS observation } \\
\text { No PSID observation } \\
\text { No PSID observation } \\
\text { No PSID observation } \\
\text { No PSID observation }\end{array}$ \\
\hline Geographical regions & $\begin{array}{l}\text { Categorical variables that differ across } \\
\text { countries: } \\
\text { - Australia: } 2011 \text { Australian Statistical } \\
\text { Geography Standard (ASGS) - Greater } \\
\text { Capital City Statistical Area } \\
\text { - UK: Government Office Regions } \\
\text { - USA: Census geographical divisions. }\end{array}$ & \\
\hline
\end{tabular}

\section{Spell-invariant variables}

There are three spell-invariant variables in the model that are measured across episodes spanning rental spells:

- Lost partner while renting

- Had additional dependent children while renting

- Lost employment while renting.

Two other spell-invariant variables are measured in the final year of home ownership spells preceding a rental spell:

- Real amounts of housing equity released upon selling up (in 2017 prices)

- User costs (detailed below).

The user cost expression for Australia and the UK is written as follows:

$$
u=(1-\tau) i+\tau i \alpha+\vartheta-\pi_{h}
$$

The user cost expression for the USA is defined as:

where

$$
u=(1-\tau) i+\vartheta-\pi_{h}
$$

$u=$ home owner's user cost

$\tau=$ marginal income tax rate of homeowner

$i=$ home loan interest rate

$\alpha=$ loan-to-value ratio

$\vartheta=$ operating costs

$\pi_{h}=$ house price appreciation rate

The two expressions differ in one key respect. The second term on the right-hand side of equation (1) is the tax penalty associated with debt finance because interest is not deductible from assessable income in Australia and the UK. It disappears in equation (2) because in the USA mortgage interest is deductible and capital gains are exempt provided they are rolled over into a subsequent purchase of housing. 


\section{Time-invariant variables}

Ethnicity is a time-invariant personal characteristic that therefore takes the same value for each person year in an individual's rental spell.

- Australia: This variable is proxied by place of birth due to missing information on ethnicity. Three groups are employed in the modelling: Born in Australia, born in mainly English-speaking countries other than Australia, and born in other countries.

- UK: White British, Black, Asian (Pakistani, Bangladeshi, Indian, and Chinese), and other ethnicity backgrounds. But due to small sample sizes, the UK ethnicity variable is merged into two groups; white British and others.

- $\quad$ USA: White, Black, and others (Hispanics, Asians and other ethnicity backgrounds).

\section{Interpretation of odds ratios}

We report the results of the models with easy-to-interpret odds ratios. For categorical variables, these measure the relative difference in the likelihood of a person returning to ownership if they are in one category of an independent variable rather than the reference category. The more the odds ratio departs from 1, the more being in one category lifts (if greater than 1) or depresses (if less than 1) the odds of returning. For example, compared to being in the reference category 'married', every other relationship status in Australia reduces the likelihood of a person returning to ownership, by $31 \%$ if separated or divorced (see Table 1). For continuous variables, the estimate shows the proportionate change in the odds of rebounding into ownership for every unit increase, e.g. in USA for every extra US $\$ 100 \mathrm{k}$ released on exiting ownership, the chances of return are lifted by $11 \%$ (see Table 1).

\section{Additional descriptives and regression analyses}

Table S2: Additional characteristics of those who returned to home ownership versus those who remained as renters, per cent by column

\begin{tabular}{|c|c|c|c|}
\hline $\cos ^{\circ}$ & Remained as renters & Returned to ownership & All \\
\hline \multicolumn{4}{|c|}{ Fixed characteristics (person-year observations) ${ }^{1}$} \\
\hline \multicolumn{4}{|l|}{ Australia (place of birth) } \\
\hline Australian-born & $79.0 \%$ & $80.7 \%$ & $79.4 \%$ \\
\hline Mainly English-speaking countries & & & \\
\hline other than Australia & $10.2 \%$ & $10.9 \%$ & $10.3 \%$ \\
\hline Other countries & $10.8 \%$ & $8.4 \%$ & $10.3 \%$ \\
\hline \multicolumn{4}{|l|}{ UK (ethnicity) } \\
\hline White (or British white) & $98.6 \%$ & $93.8 \%$ & $98.0 \%$ \\
\hline Black & $0.0 \%$ & $0.6 \%$ & $0.1 \%$ \\
\hline Asian $^{1}$ & $1.4 \%$ & $4.5 \%$ & $1.8 \%$ \\
\hline Other ethnicity backgrounds² & $0.0 \%$ & $1.1 \%$ & $0.1 \%$ \\
\hline \multicolumn{4}{|l|}{ US (ethnicity) } \\
\hline White & $87.1 \%$ & $87.3 \%$ & $87.1 \%$ \\
\hline Black & $9.0 \%$ & $7.9 \%$ & $8.7 \%$ \\
\hline Others $^{3}$ & $3.9 \%$ & $4.8 \%$ & $4.1 \%$ \\
\hline
\end{tabular}




\begin{tabular}{|c|c|c|c|}
\hline & Remained as renters & Returned to ownership & All \\
\hline \multicolumn{4}{|c|}{ Australia (2011 ASGS Greater } \\
\hline \multicolumn{4}{|l|}{ Capital City) } \\
\hline Greater Sydney & $13.4 \%$ & $13.3 \%$ & $13.4 \%$ \\
\hline Rest of NSW & $15.5 \%$ & $14.8 \%$ & $15.0 \%$ \\
\hline Greater Melbourne & $13.6 \%$ & $15.0 \%$ & $14.5 \%$ \\
\hline Rest of Victoria & $8.5 \%$ & $6.4 \%$ & $7.1 \%$ \\
\hline Greater Brisbane & $10.1 \%$ & $11.6 \%$ & $11.1 \%$ \\
\hline Rest of Qld & $14.5 \%$ & $13.0 \%$ & $13.5 \%$ \\
\hline Greater Adelaide & $4.2 \%$ & $6.5 \%$ & $5.7 \%$ \\
\hline Rest of SA & $4.9 \%$ & $2.1 \%$ & $3.0 \%$ \\
\hline Greater Perth & $7.1 \%$ & $8.7 \%$ & $8.1 \%$ \\
\hline Rest of WA & $2.8 \%$ & $2.5 \%$ & $2.6 \%$ \\
\hline Tasmania & $4.2 \%$ & $2.8 \%$ & $3.3 \%$ \\
\hline Northern Territory & $0.5 \%$ & $1.5 \%$ & $1.2 \%$ \\
\hline ACT & $0.7 \%$ & $1.9 \%$ & $1.5 \%$ \\
\hline \multicolumn{4}{|c|}{ UK (Government Office Regions) } \\
\hline North East & $3.3 \%$ & $1.7 \%$ & $2.5 \%$ \\
\hline North West & $9.2 \%$ & $7.9 \%$ & $8.6 \%$ \\
\hline Yorkshire \& Humber & $2.7 \%$ & $3.4 \%$ & $3.0 \%$ \\
\hline East Midlands & $11.4 \%$ & $7.9 \%$ & $9.7 \%$ \\
\hline West Midlands & $1.6 \%$ & $8.5 \%$ & $5.0 \%$ \\
\hline East of England & $6.0 \%$ & $5.6 \%$ & $5.8 \%$ \\
\hline London & $2.2 \%$ & $5.1 \%$ & $3.6 \%$ \\
\hline South East & $3.8 \%$ & $10.7 \%$ & $7.2 \%$ \\
\hline South West & $7.1 \%$ & $6.8 \%$ & $6.9 \%$ \\
\hline Wales & $17.4 \%$ & $10.2 \%$ & $13.9 \%$ \\
\hline Scotland & $13.0 \%$ & $15.3 \%$ & $14.1 \%$ \\
\hline Northern Ireland & $22.3 \%$ & $16.9 \%$ & $19.7 \%$ \\
\hline \multicolumn{4}{|l|}{ US (Divisions) } \\
\hline New England & $3.1 \%$ & $2.8 \%$ & $2.9 \%$ \\
\hline Middle Atlantic & $10.0 \%$ & $9.8 \%$ & $9.9 \%$ \\
\hline East North Atlantic & $16.1 \%$ & $12.6 \%$ & $14.1 \%$ \\
\hline West North Atlantic & $9.0 \%$ & $11.5 \%$ & $10.4 \%$ \\
\hline South Atlantic & $21.6 \%$ & $20.0 \%$ & $20.7 \%$ \\
\hline East South Central & $6.5 \%$ & $8.1 \%$ & $7.4 \%$ \\
\hline West South Central & $10.0 \%$ & $14.8 \%$ & $12.8 \%$ \\
\hline Mountain & $8.8 \%$ & $9.4 \%$ & $9.1 \%$ \\
\hline Pacific & $14.9 \%$ & $11.2 \%$ & $12.8 \%$ \\
\hline
\end{tabular}

Source: Authors' calculations using the 2001-2017 HILDA, 2001-2008 BHPS, 2010-2017 UKHLS, and 20012017 PSID

Notes:

${ }^{1}$ Asian includes Bangladeshi, Pakistani, Indian, and Chinese.

20ther ethnicity backgrounds include other Asian countries, mixed ethnicity background, and others.

${ }^{3}$ Other ethnicity backgrounds include Hispanics and other ethnicity backgrounds. 
Table S3: Transition probabilities, per cent by row

\begin{tabular}{|c|c|c|c|c|c|c|c|c|c|}
\hline \multirow[b]{2}{*}{ Year } & \multicolumn{3}{|c|}{ Australia } & \multicolumn{3}{|c|}{ UK } & \multicolumn{3}{|c|}{ USA } \\
\hline & $\begin{array}{c}\text { Remained } \\
\text { as renter } \\
(\%)\end{array}$ & $\begin{array}{c}\text { Returned } \\
\text { to } \\
\text { ownership } \\
(\%)\end{array}$ & All & $\begin{array}{c}\text { Remaine } \\
\text { d as } \\
\text { renter } \\
(\%)\end{array}$ & $\begin{array}{c}\text { Returned } \\
\text { to } \\
\text { ownership } \\
(\%)\end{array}$ & All & $\begin{array}{c}\text { Remained } \\
\text { as renter } \\
(\%)\end{array}$ & $\begin{array}{c}\text { Returned } \\
\text { to } \\
\text { ownership } \\
(\%)\end{array}$ & All \\
\hline 2002 & 53.0 & 47.0 & 100.0 & 55.9 & 44.1 & 100.0 & & & \\
\hline 2003 & 64.7 & 35.3 & 100.0 & 74.6 & 25.4 & 100.0 & 62.5 & 37.5 & 100.0 \\
\hline 2004 & 72.0 & 28.0 & 100.0 & 87.5 & 12.5 & 100.0 & & 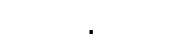 & \\
\hline 2005 & 72.5 & 27.5 & 100.0 & 80.4 & 19.6 & 100.0 & 68.0 & 32.0 & 100.0 \\
\hline 2006 & 74.7 & 25.4 & 100.0 & 80.9 & 19.1 & 100.0 & & & \\
\hline 2007 & 75.8 & 24.2 & 100.0 & 84.8 & 15.2 & 100.0 & 74.4 & 25.7 & 100.0 \\
\hline 2008 & 79.8 & 20.2 & 100.0 & 81.6 & 18.4 & 100.0 & & 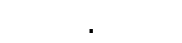 & \\
\hline 2009 & 78.0 & 22.0 & 100.0 & & & & 79.9 & 20.1 & 100.0 \\
\hline 2010 & 81.5 & 18.5 & 100.0 & 94.5 & 5.5 & 100.0 & & & \\
\hline 2011 & 81.6 & 18.4 & 100.0 & 96.4 & 3.6 & 100.0 & 77.8 & 22.2 & 100.0 \\
\hline 2012 & 83.0 & 17.0 & 100.0 & 90.7 & 9.4 & 100.0 & & 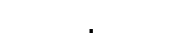 & \\
\hline 2013 & 82.7 & 17.3 & 100.0 & 95.7 & 4.4 & 100.0 & 75.3 & 24.7 & 100.0 \\
\hline 2014 & 80.9 & 19.2 & 100.0 & 92.3 & 7.7 & 100.0 & & . & \\
\hline 2015 & 83.4 & 16.6 & 100.0 & 89.6 & 10.4 & 100.0 & 77.7 & 22.3 & 100.0 \\
\hline 2016 & 85.2 & 14.8 & 100.0 & 90.8 & 9.2 & 100.0 & & & \\
\hline
\end{tabular}

Source: Authors' calculations from 2001-2017 HILDA, 2001-2008 BHPS, 2010-2017 UKHLS, 2001-2017 PSID

Figure S1: Home loan rates, 2001-2017, per cent ${ }^{1,2}$

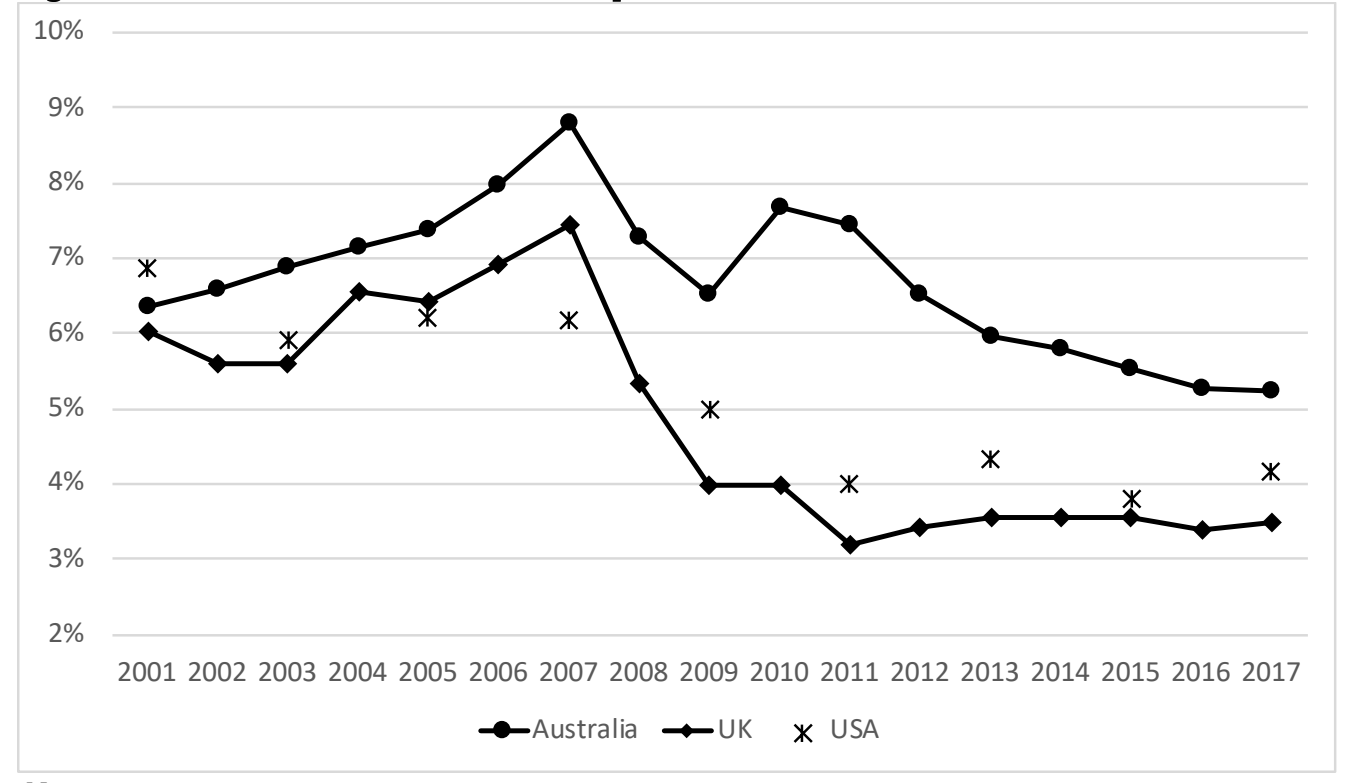

Notes:

${ }^{1}$ For all countries, the rates are averages for financial months defining the financial year (July-June) in Australia. In Australia, the series FILRHBVS from the Reserve Bank of Australia is used. For the UK, we utilise two series from the Bank of England: the series CFMBX2D is used for rates between 2001-2015, and the series CFMZ6IX is used for rates in 2016 and 2017. For the USA, the mortgage rates were obtained from Freddie Mac's 30-year fixed rate mortgage average, which were collected from their Primary Mortgage Market Survey.

${ }^{2}$ Home loan interest rates are a major driver of the real user cost of housing (see equations 1 and 2). 
Table S4: Full regression results for Australia, 2001-20171, 2

\begin{tabular}{|c|c|c|c|c|c|c|c|c|c|c|c|c|}
\hline \multirow[b]{2}{*}{ Explanatory variables } & \multicolumn{3}{|c|}{ Model 1: Age Categories } & \multicolumn{3}{|c|}{$\begin{array}{l}\text { Model 2: Age Categories, Ethnicity } \\
\text { and Regions }\end{array}$} & \multicolumn{3}{|c|}{ Model 3: Continuous Age } & \multicolumn{3}{|c|}{$\begin{array}{l}\text { Model 4: Continuous Age, } \\
\text { Ethnicity and Regions }\end{array}$} \\
\hline & Coeff. & $\begin{array}{l}\text { Std. } \\
\text { error }\end{array}$ & $\begin{array}{l}\text { Odds } \\
\text { ratio }\end{array}$ & Coeff. & $\begin{array}{l}\text { Std. } \\
\text { error }\end{array}$ & $\begin{array}{l}\text { Odds } \\
\text { ratio }\end{array}$ & Coeff. & $\begin{array}{l}\text { Std. } \\
\text { error }\end{array}$ & $\begin{array}{l}\text { Odds } \\
\text { ratio }\end{array}$ & Coeff. & $\begin{array}{l}\text { Std. } \\
\text { error }\end{array}$ & $\begin{array}{l}\text { Odds } \\
\text { ratio }\end{array}$ \\
\hline \multicolumn{13}{|l|}{ LIFE CYCLE (AGE) } \\
\hline Age & & & & & & & $0.093^{* * *}$ & 0.025 & $1.097^{* * *}$ & $0.092^{* * *}$ & 0.025 & $1.097^{* * *}$ \\
\hline $\mathrm{Age}^{2} / 100$ & & & & & & & $-0.093^{* * *}$ & 0.023 & $0.911^{* * *}$ & $-0.093^{* * *}$ & 0.023 & $0.911^{* * *}$ \\
\hline $35-44$ years old & -0.0609 & 0.150 & 0.941 & -0.0778 & 0.150 & 0.925 & & & & & & \\
\hline 45-54 years old & 0.106 & 0.172 & 1.112 & 0.111 & 0.173 & 1.118 & & & & & & \\
\hline 55-64 years old & $0.409 * *$ & 0.202 & $1.506^{* *}$ & $0.390^{*}$ & 0.204 & $1.476^{*}$ & & & & & & \\
\hline 65 years and above & -0.249 & 0.235 & 0.779 & -0.265 & 0.237 & 0.767 & & & & & & \\
\hline HOUSEHOLD STRUCTURE & & & & & & & & & & & & \\
\hline De facto & -0.170 & 0.162 & 0.844 & -0.169 & 0.162 & 0.844 & -0.206 & 0.163 & 0.814 & -0.201 & 0.163 & 0.818 \\
\hline Separated/Divorced & $-0.339 * *$ & 0.143 & $0.713^{* *}$ & $-0.371^{* * *}$ & 0.143 & $0.690^{* * *}$ & $-0.387^{* * *}$ & 0.144 & $0.679 * * *$ & $-0.418^{* * *}$ & 0.144 & $0.658^{* * *}$ \\
\hline Widowed & -0.215 & 0.223 & 0.807 & -0.197 & 0.223 & 0.821 & 0.0219 & 0.238 & 1.022 & 0.0361 & 0.238 & 1.037 \\
\hline Single/Never married & $-0.588^{* * *}$ & 0.196 & $0.555^{* * *}$ & $-0.578^{* * *}$ & 0.196 & $0.561^{* * *}$ & $-0.596^{* * *}$ & 0.198 & $0.551^{* * *}$ & $-0.583^{* * *}$ & 0.198 & $0.558 * * *$ \\
\hline Loss partner while renting & $-0.885^{* * *}$ & 0.135 & $0.413^{* * *}$ & $-0.871^{* * *}$ & 0.135 & $0.419^{* * *}$ & $-0.906^{* * *}$ & 0.136 & $0.404^{* * *}$ & $-0.890^{* * *}$ & 0.136 & $0.410^{* * *}$ \\
\hline Dependent children present & $0.282^{* *}$ & 0.130 & $1.326^{* *}$ & $0.301^{* *}$ & 0.130 & $1.351^{* *}$ & 0.171 & 0.127 & 1.186 & 0.188 & 0.127 & 1.207 \\
\hline $\begin{array}{l}\text { Had additional dependent } \\
\text { children while renting } \\
\text { HEALTH, WEALTH \& INCOME }\end{array}$ & $-0.481^{* * *}$ & 0.140 & $0.618^{* * *}$ & $-0.478^{* * *}$ & 0.140 & $0.620^{* * *}$ & $-0.467^{* * *}$ & 0.141 & $0.627^{* * *}$ & $-0.464^{* * *}$ & 0.141 & $0.629^{* * *}$ \\
\hline Fair to poor health & $-0.403^{* * *}$ & 0.124 & $0.668^{* * *}$ & $-0.429^{* * *}$ & 0.124 & $0.651^{* * *}$ & $-0.381^{* * *}$ & 0.124 & $0.683^{* * *}$ & $-0.404^{* * *}$ & 0.125 & $0.668^{* * *}$ \\
\hline Highest qualification: Tertiary & $0.303^{* *}$ & 0.124 & $1.354^{* *}$ & $0.305^{* *}$ & 0.124 & $1.357^{* *}$ & $0.296^{* *}$ & 0.125 & $1.344^{* *}$ & $0.296^{* *}$ & 0.125 & $1.345^{* *}$ \\
\hline Employed & $0.371^{* * *}$ & 0.128 & $1.450^{* * *}$ & $0.378^{* * *}$ & 0.128 & $1.459^{* * *}$ & $0.320^{* *}$ & 0.127 & $1.377^{* *}$ & $0.329^{* * *}$ & 0.127 & $1.390^{* * *}$ \\
\hline $\begin{array}{l}\text { Loss of employment while } \\
\text { renting }\end{array}$ & $-1.115^{* * *}$ & 0.129 & $0.328^{* * *}$ & $-1.113^{* * *}$ & 0.130 & $0.329^{* * *}$ & $-1.132^{* * *}$ & 0.13 & $0.322^{* * *}$ & $-1.126^{* * *}$ & 0.131 & $0.324^{* * *}$ \\
\hline $\begin{array}{l}\text { User cost from last } \\
\text { observation in home }\end{array}$ & & & & & & & & & & & & \\
\hline ownership & -0.0131 & 0.0553 & 0.987 & -0.0250 & 0.0558 & 0.975 & -0.0142 & 0.0557 & 0.986 & -0.0255 & 0.0562 & 0.975 \\
\hline $\begin{array}{l}\text { Real amount of equity release } \\
\text { upon selling up }\end{array}$ & & & & & & & & & & & & \\
\hline $\begin{array}{l}\text { (AU\$/£/US\$00,000) } \\
\text { Received inheritance i }\end{array}$ & $0.0512^{* * *}$ & 0.0144 & $1.053^{* * *}$ & $0.0523^{* * *}$ & 0.0145 & $1.054^{* * *}$ & $0.0516^{* * *}$ & 0.0145 & $1.053^{* * *}$ & $0.0523^{* * *}$ & 0.0147 & $1.054^{* * *}$ \\
\hline last financial year & $0.595^{*}$ & 0.345 & $1.814^{*}$ & 0.559 & 0.346 & 1.748 & $0.603^{*}$ & 0.346 & $1.828^{*}$ & 0.567 & 0.347 & 1.762 \\
\hline $\begin{array}{l}\text { Received parental gift/transfer } \\
\geq A U \$ 5,000 \text { in last financial }\end{array}$ & & & & & & & & & & & & \\
\hline $\begin{array}{l}\text { year } \\
\text { HOUSING }\end{array}$ & 0.157 & 0.517 & 1.170 & 0.136 & 0.517 & 1.146 & 0.158 & 0.518 & 1.171 & 0.137 & 0.517 & 1.147 \\
\hline Social housing & $-1.038^{* * *}$ & 0.273 & $0.354^{* * *}$ & $-1.047^{* * *}$ & 0.275 & $0.351^{* * *}$ & $-1.044^{* * *}$ & 0.276 & $0.352^{* * *}$ & $-1.056^{* * *}$ & 0.278 & $0.348^{* * *}$ \\
\hline $\begin{array}{l}\text { Rent-free } \\
\text { CALENDAR YEAR }\end{array}$ & $0.284^{* *}$ & 0.115 & $1.329^{* *}$ & $0.312^{* * *}$ & 0.116 & $1.366^{* * *}$ & $0.313^{* * *}$ & 0.116 & $1.367^{* * *}$ & $0.341^{* * *}$ & 0.117 & $1.406^{* * *}$ \\
\hline 2003 & -0.246 & 0.276 & 0.782 & -0.263 & 0.276 & 0.769 & -0.252 & 0.277 & 0.778 & -0.267 & 0.277 & 0.766 \\
\hline 2004 & $-0.555^{* *}$ & 0.274 & $0.574^{* *}$ & $-0.539 * *$ & 0.274 & $0.583^{* *}$ & $-0.566^{* *}$ & 0.275 & $0.568^{* *}$ & $-0.547^{* *}$ & 0.275 & $0.579^{* *}$ \\
\hline
\end{tabular}




\begin{tabular}{|c|c|c|c|c|c|c|c|c|c|c|c|c|}
\hline \multirow[b]{2}{*}{ Explanatory variables } & \multicolumn{3}{|c|}{ Model 1: Age Categories } & \multicolumn{3}{|c|}{$\begin{array}{l}\text { Model 2: Age Categories, Ethnicity } \\
\text { and Regions }\end{array}$} & \multicolumn{3}{|c|}{ Model 3: Continuous Age } & \multicolumn{3}{|c|}{$\begin{array}{l}\text { Model 4: Continuous Age, } \\
\text { Ethnicity and Regions }\end{array}$} \\
\hline & Coeff. & $\begin{array}{l}\text { Std. } \\
\text { error }\end{array}$ & $\begin{array}{l}\text { Odds } \\
\text { ratio }\end{array}$ & Coeff. & $\begin{array}{l}\text { Std. } \\
\text { error }\end{array}$ & $\begin{array}{l}\text { Odds } \\
\text { ratio }\end{array}$ & Coeff. & $\begin{array}{l}\text { Std. } \\
\text { error }\end{array}$ & $\begin{array}{l}\text { Odds } \\
\text { ratio }\end{array}$ & Coeff. & $\begin{array}{l}\text { Std. } \\
\text { error }\end{array}$ & $\begin{array}{l}\text { Odds } \\
\text { ratio }\end{array}$ \\
\hline 2005 & $-0.647^{* *}$ & 0.265 & $0.524^{* *}$ & $-0.621^{* *}$ & 0.265 & $0.538^{* *}$ & $-0.654^{* *}$ & 0.267 & $0.520^{* *}$ & $-0.625^{* *}$ & 0.266 & $0.536^{* *}$ \\
\hline 2006 & $-0.798^{* * *}$ & 0.263 & $0.450^{* * *}$ & $-0.776^{* * *}$ & 0.263 & $0.460^{* * *}$ & $-0.806^{* * *}$ & 0.265 & $0.446^{* * *}$ & $-0.781^{* * *}$ & 0.264 & $0.458^{* * *}$ \\
\hline 2007 & $-0.742^{* * *}$ & 0.267 & $0.476^{* * *}$ & $-0.729 * * *$ & 0.267 & $0.482^{* * *}$ & $-0.759^{* * *}$ & 0.269 & $0.468^{* * *}$ & $-0.744^{* * *}$ & 0.268 & $0.475^{* * *}$ \\
\hline 2008 & $-0.909 * * *$ & 0.277 & $0.403^{* * *}$ & $-0.907^{* * *}$ & 0.277 & $0.404^{* * *}$ & $-0.935^{* * *}$ & 0.279 & $0.392^{* * *}$ & $-0.929 * * *$ & 0.279 & $0.395^{* * *}$ \\
\hline 2009 & $-0.886^{* * *}$ & 0.267 & $0.413^{* * *}$ & $-0.890^{* * *}$ & 0.267 & $0.411^{* * *}$ & $-0.911^{* * *}$ & 0.269 & $0.402^{* * *}$ & $-0.913^{* * *}$ & 0.269 & $0.401^{* * *}$ \\
\hline 2010 & $-1.149 * * *$ & 0.266 & $0.317^{* * *}$ & $-1.166^{* * *}$ & 0.266 & $0.312^{* * *}$ & $-1.186^{* * *}$ & 0.268 & $0.305^{* * *}$ & $-1.198^{* * *}$ & 0.268 & $0.302^{* * *}$ \\
\hline 2011 & $-1.130^{* * *}$ & 0.271 & $0.323^{* * *}$ & $-1.132^{* * *}$ & 0.271 & $0.322^{* * *}$ & $-1.149^{* * *}$ & 0.273 & $0.317^{* * *}$ & $-1.147^{* * *}$ & 0.273 & $0.318^{* * *}$ \\
\hline 2012 & $-1.118^{* * *}$ & 0.270 & $0.327^{* * *}$ & $-1.118^{* * *}$ & 0.270 & $0.327^{* * *}$ & $-1.143^{* * *}$ & 0.272 & $0.319^{* * *}$ & $-1.140^{* * *}$ & 0.272 & $0.320^{* * *}$ \\
\hline 2013 & $-1.117^{* * *}$ & 0.267 & $0.327^{* * *}$ & $-1.108^{* * *}$ & 0.267 & $0.330^{* * *}$ & $-1.156^{* * *}$ & 0.27 & $0.315^{* * *}$ & $-1.144^{* * *}$ & 0.270 & $0.318^{* * *}$ \\
\hline 2014 & $-1.008^{* * *}$ & 0.264 & $0.365^{* * *}$ & $-1.001^{* * *}$ & 0.264 & $0.367^{* * *}$ & $-1.041^{* * *}$ & 0.266 & $0.353^{* * *}$ & $-1.033^{* * *}$ & 0.266 & $0.356^{* * *}$ \\
\hline 2015 & $-1.220 * * *$ & 0.268 & $0.295^{* * *}$ & $-1.216^{* * *}$ & 0.268 & $0.297^{* * *}$ & $-1.237^{* * *}$ & 0.27 & $0.290^{* * *}$ & $-1.231^{* * *}$ & 0.270 & $0.292^{* * *}$ \\
\hline 2016 & $-1.430^{* * *}$ & 0.268 & $0.239 * * *$ & $-1.411^{* * *}$ & 0.268 & $0.244^{* * *}$ & $-1.439 * * *$ & 0.27 & $0.237^{* * *}$ & $-1.417^{* * *}$ & 0.270 & $0.242^{* * *}$ \\
\hline \multicolumn{13}{|l|}{ ETHNICITY3 } \\
\hline $\begin{array}{l}\text { Mainly English-speaking } \\
\text { countries other than Australia }\end{array}$ & & & & 0.196 & 0.178 & 1.216 & & & & 0.199 & 0.180 & 1.220 \\
\hline Other countries & & & & $-0.348^{*}$ & 0.186 & $0.706^{*}$ & & & & $-0.362^{*}$ & 0.188 & $0.696^{*}$ \\
\hline \multicolumn{13}{|l|}{ GREATER CAPITAL CITY4 } \\
\hline Rest of NSW & & & & 0.163 & 0.197 & 1.178 & & & & 0.170 & 0.199 & 1.185 \\
\hline Greater Melbourne & & & & 0.177 & 0.198 & 1.193 & & & & 0.171 & 0.200 & 1.186 \\
\hline Rest of Victoria & & & & 0.0888 & 0.244 & 1.093 & & & & 0.0902 & 0.246 & 1.094 \\
\hline Greater Brisbane & & & & 0.194 & 0.212 & 1.214 & & & & 0.171 & 0.213 & 1.187 \\
\hline Rest of Qld & & & & 0.185 & 0.207 & 1.203 & & & & 0.153 & 0.208 & 1.165 \\
\hline Greater Adelaide & & & & $0.751^{* * *}$ & 0.260 & $2.120^{* * *}$ & & & & $0.724^{* * *}$ & 0.262 & $2.063^{* * *}$ \\
\hline Rest of SA & & & & -0.131 & 0.347 & 0.877 & & & & -0.164 & 0.350 & 0.848 \\
\hline Greater Perth & & & & $0.429^{*}$ & 0.234 & $1.535^{*}$ & & & & $0.458^{*}$ & 0.236 & $1.581^{*}$ \\
\hline Rest of WA & & & & 0.171 & 0.343 & 1.186 & & & & 0.178 & 0.346 & 1.194 \\
\hline Tasmania & & & & 0.0202 & 0.335 & 1.020 & & & & 0.00186 & 0.338 & 1.002 \\
\hline Norther Territory & & & & -0.233 & 0.452 & 0.792 & & & & -0.283 & 0.454 & 0.754 \\
\hline ACT & & & & 0.646 & 0.396 & 1.907 & & & & 0.601 & 0.399 & 1.823 \\
\hline Constant & 0.061 & 0.370 & 1.063 & -0.0834 & 0.393 & 0.920 & $-1.915^{* * *}$ & 0.726 & $0.147^{* * *}$ & $-2.048^{* * *}$ & 0.734 & $0.129 * * *$ \\
\hline Observations & 5,511 & & & 5,510 & & & 5,511 & & & 5,510 & & \\
\hline Number of individuals & 1,420 & & & 1,420 & & & 1,420 & & & 1,420 & & \\
\hline Wald-chi2 & $357.05^{* * *}$ & & & $371.07^{* * *}$ & & & $353.91^{* * *}$ & & & $368.29^{* * *}$ & & \\
\hline LR test of rho $=0$ & $158.57^{* * *}$ & & & $147.02^{* * *}$ & & & $167.25^{* * *}$ & & & $153.60^{* * *}$ & & \\
\hline
\end{tabular}

Source: Authors' calculations using the 2001-2017 HILDA.

Notes:

${ }^{* * *}$ significant at $1 \%$ level, ${ }^{* *}$ significant at $5 \%$ level, and * significant at $10 \%$ level.

${ }^{1}$ The omitted reference categories are: $<35$ years old, married, did not lose a partner while renting, no dependent children, did not have additional dependent children while

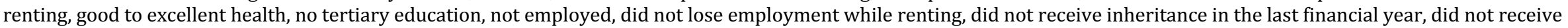
a parental gift of AU $\$ 5000$ or more, and private renters, born in Australia, from Greater Sydney, and year 2002. 
2We experimented with various specifications that allow for alternative definitions of age, the inclusion or otherwise of ethnicity and geographical (region) controls:

- Column 1 reports estimates on omitting ethnicity and region controls and employing age categories.

- Column 2 adds ethnicity and region controls.

- Column 3 omits ethnicity and region controls but replaces age categories by a continuous version of age.

- $\quad$ Column 4 adds ethnicity and region controls back into the specification.

3The ethnicity variable reflects place of birth.

${ }^{4}$ Geographical variables include ASGS 2011 greater capital city statistical areas in Australia. 
Table S5: Full regression results for the UK, 2001-20171, 2

\begin{tabular}{|c|c|c|c|c|c|c|c|c|c|c|c|c|}
\hline \multirow[b]{2}{*}{ Explanatory variables } & \multicolumn{3}{|c|}{ Model 1: Age Categories } & \multicolumn{3}{|c|}{$\begin{array}{l}\text { Model 2: Age Categories, Ethnicity } \\
\text { and Regions }\end{array}$} & \multicolumn{3}{|c|}{ Model 3: Continuous Age } & \multicolumn{3}{|c|}{$\begin{array}{l}\text { Model 4: Continuous Age, } \\
\text { Ethnicity and Regions }\end{array}$} \\
\hline & Coeff. & $\begin{array}{l}\text { Std. } \\
\text { error }\end{array}$ & Odds ratio & Coeff. & $\begin{array}{l}\text { Std. } \\
\text { error }\end{array}$ & Odds ratio & Coeff. & $\begin{array}{l}\text { Std. } \\
\text { error }\end{array}$ & Odds ratio & Coeff. & $\begin{array}{l}\text { Std. } \\
\text { error }\end{array}$ & $\begin{array}{l}\text { Odds } \\
\text { ratio }\end{array}$ \\
\hline \multicolumn{13}{|l|}{ LIFE CYCLE (AGE) } \\
\hline Age (continuous) & & & & & & & 0.00124 & 0.0576 & 1.001 & 0.0239 & 0.0588 & 1.024 \\
\hline Age $2 / 100$ & & & & & & & -0.0269 & 0.052 & 0.973 & -0.0470 & 0.0531 & 0.954 \\
\hline $35-44$ years old & -0.260 & 0.403 & 0.771 & -0.285 & 0.418 & 0.752 & & & & & & \\
\hline 45-54 years old & -0.406 & 0.487 & 0.666 & -0.306 & 0.493 & 0.736 & & & & & & \\
\hline $55-64$ years old & -0.450 & 0.565 & 0.638 & -0.391 & 0.573 & 0.676 & & & & & & \\
\hline 65 years and above & $-1.434^{* *}$ & 0.628 & $0.238^{* *}$ & $-1.476^{* *}$ & 0.631 & $0.229^{* *}$ & & & & & & \\
\hline \multicolumn{13}{|l|}{ HOUSEHOLD STRUCTURE } \\
\hline De facto & 0.633 & 0.495 & 1.884 & 0.826 & 0.512 & 2.285 & 0.607 & 0.489 & 1.835 & 0.809 & 0.509 & 2.245 \\
\hline Separated/Divorced & $0.739^{*}$ & 0.402 & $2.094^{*}$ & $0.858^{* *}$ & 0.407 & $2.359^{* *}$ & $0.755^{*}$ & 0.391 & $2.128^{*}$ & $0.873^{* *}$ & 0.397 & $2.394^{* *}$ \\
\hline Widowed & 0.173 & 0.553 & 1.189 & 0.394 & 0.562 & 1.482 & 0.287 & 0.586 & 1.333 & 0.549 & 0.599 & 1.732 \\
\hline Single/Never married & 0.688 & 0.432 & 1.990 & $0.752^{*}$ & 0.44 & $2.122^{*}$ & 0.668 & 0.429 & 1.951 & $0.763^{*}$ & 0.44 & $2.145^{*}$ \\
\hline Loss partner while renting & $-1.076^{* * *}$ & 0.356 & $0.341^{* * *}$ & $-1.008^{* * *}$ & 0.353 & $0.365^{* * *}$ & $-1.127^{* * *}$ & 0.355 & $0.324^{* * *}$ & $-1.070^{* * *}$ & 0.353 & $0.343^{* * *}$ \\
\hline Dependent children present & -0.114 & 0.385 & 0.892 & -0.160 & 0.391 & 0.852 & -0.151 & 0.365 & 0.860 & -0.202 & 0.373 & 0.817 \\
\hline $\begin{array}{l}\text { Had additional dependent } \\
\text { children while renting }\end{array}$ & $-0.974 * *$ & 0.471 & $0.378 * *$ & $-0.830 *$ & 0.486 & $0.436^{*}$ & $-0.974 * *$ & 0.468 & $0.378 * *$ & $-0.809 *$ & 0.483 & $0.445^{*}$ \\
\hline HEALTH, WEALTH \& INCOME & & & & & & & & & $0.3 / 0$ & -0.009 & 0.403 & 0.445 \\
\hline Fair to poor health & -0.301 & 0.29 & 0.740 & -0.372 & 0.296 & 0.690 & -0.284 & 0.289 & 0.753 & -0.357 & 0.295 & 0.700 \\
\hline Highest qualification: Tertiary & $1.174^{* * *}$ & 0.374 & $3.235^{* * *}$ & $0.957^{* *}$ & 0.382 & $2.604^{* *}$ & $1.157^{* * *}$ & 0.372 & $3.181^{* * *}$ & $0.967^{* *}$ & 0.38 & $2.629^{* *}$ \\
\hline Employed & 0.563 & 0.357 & 1.755 & 0.565 & 0.359 & 1.759 & $0.616^{*}$ & 0.352 & $1.851^{*}$ & $0.624^{*}$ & 0.355 & $1.866^{*}$ \\
\hline $\begin{array}{l}\text { Loss of employment while } \\
\text { renting }\end{array}$ & $-0.955^{* *}$ & 0.389 & $0.385^{* *}$ & $-1.011^{* * *}$ & 0.392 & $0.364^{* * *}$ & $-0.913^{* *}$ & 0.382 & $0.401^{* *}$ & $-0.970^{* *}$ & 0.386 & $0.379 * *$ \\
\hline $\begin{array}{l}\text { User cost from last observation } \\
\text { in home ownership }\end{array}$ & $-0.686^{* * *}$ & 0.185 & $0.503^{* * *}$ & $-0.734 * * *$ & 0.19 & $0.480^{* * *}$ & $-0.694^{* * *}$ & 0.185 & $0.499 * * *$ & $-0.734 * * *$ & 0.189 & $0.480^{* * *}$ \\
\hline $\begin{array}{l}\text { Real amount of equity release } \\
\text { upon selling up }\end{array}$ & & & & & & & & & & & & \\
\hline $\begin{array}{l}(\text { AU } \$ / £ / U S \$ 00,000) \\
\text { HOUSING }\end{array}$ & 0.126 & 0.13 & 1.135 & 0.175 & 0.138 & 1.191 & 0.130 & 0.128 & 1.139 & 0.172 & 0.136 & 1.188 \\
\hline Social housing & $-1.534^{* * *}$ & 0.446 & $0.216^{* * *}$ & $-1.453^{* * *}$ & 0.447 & $0.234^{* * *}$ & $-1.550^{* * *}$ & 0.442 & $0.212^{* * *}$ & $-1.479^{* * *}$ & 0.445 & $0.228^{* * *}$ \\
\hline Rent-free & 0.349 & 0.309 & 1.418 & 0.433 & 0.314 & 1.542 & 0.340 & 0.306 & 1.405 & 0.433 & 0.312 & 1.542 \\
\hline CALENDAR YEAR & & & & & & & & & & & & \\
\hline 2003 & $-1.251^{*}$ & 0.655 & $0.286^{*}$ & -1.069 & 0.657 & 0.343 & $-1.208^{*}$ & 0.65 & $0.299 *$ & -1.039 & 0.653 & 0.354 \\
\hline 2004 & $-2.124^{* * *}$ & 0.669 & $0.120^{* * *}$ & $-2.048^{* * *}$ & 0.668 & $0.129^{* * *}$ & $-2.070^{* * *}$ & 0.663 & $0.126^{* * *}$ & $-2.002^{* * *}$ & 0.663 & $0.135^{* * *}$ \\
\hline 2005 & $-1.067^{*}$ & 0.604 & $0.344^{*}$ & $-1.068^{*}$ & 0.605 & $0.344^{*}$ & $-1.024^{*}$ & 0.602 & $0.359 *$ & $-1.025^{*}$ & 0.604 & $0.359 *$ \\
\hline 2006 & $-1.292^{* *}$ & 0.604 & $0.275^{* *}$ & $-1.310^{* *}$ & 0.611 & $0.270^{* *}$ & $-1.264^{* *}$ & 0.601 & $0.283^{* *}$ & $-1.299^{* *}$ & 0.609 & $0.273^{* *}$ \\
\hline 2007 & $-1.267^{* *}$ & 0.614 & $0.282^{* *}$ & $-1.548^{* *}$ & 0.635 & $0.213^{* *}$ & $-1.221^{* *}$ & 0.611 & $0.295^{* *}$ & $-1.513^{* *}$ & 0.634 & $0.220^{* *}$ \\
\hline 2008 & -0.733 & 0.605 & 0.480 & -0.722 & 0.61 & 0.486 & -0.679 & 0.602 & 0.507 & -0.683 & 0.609 & 0.505 \\
\hline 2009 & & & . & & & & . & & & & & \\
\hline 2010 & $-2.951^{* * *}$ & 0.709 & $0.0523^{* * *}$ & $-2.973^{* * *}$ & 0.716 & $0.0511^{* * *}$ & $-2.871^{* * *}$ & 0.703 & $0.0566^{* * *}$ & $-2.909^{* * *}$ & 0.712 & $0.0545^{* * *}$ \\
\hline
\end{tabular}




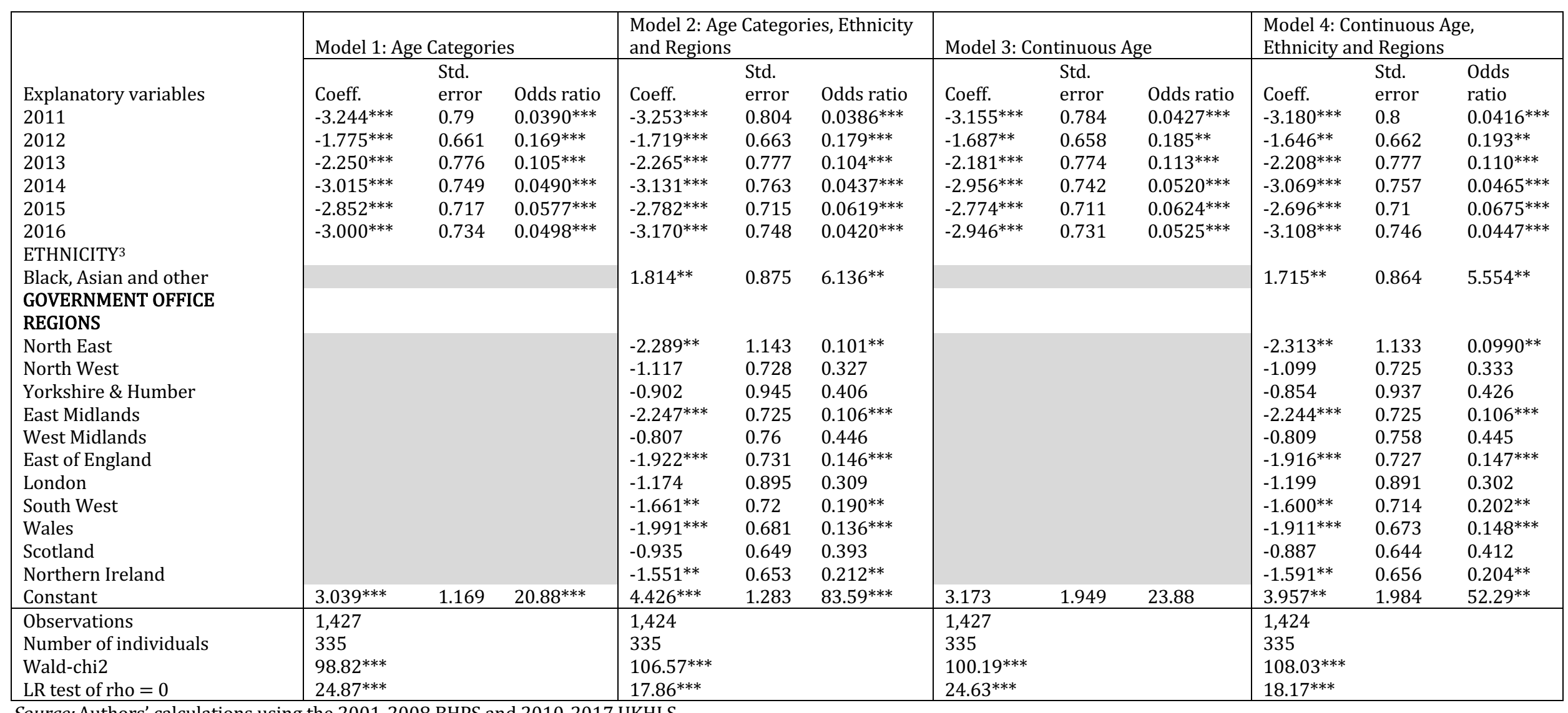

Source: Authors' calculations using the 2001-2008 BHPS and 2010-2017 UKHLS

Notes:

*** significant at $1 \%$ level, ** significant at $5 \%$ level, and * significant at $10 \%$ level.

1 The omitted reference categories are: $<35$ years old, married, did not lose a partner while renting, no dependent children, did not have additional dependent children while

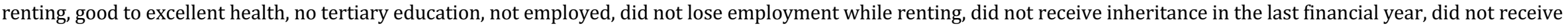
a parental gift of AU $\$ 5000$ or more, and private renters, white British, from the South East region, and year 2002.

2We experimented with various specifications that allow for alternative definitions of age, the inclusion or otherwise of ethnicity and geographical (region) controls:

- Column 1 reports estimates on omitting ethnicity and region controls and employing age categories.

- Column 2 adds ethnicity and region controls.

- Column 3 omits ethnicity and region controls but replaces age categories by a continuous version of age.

- Column 4 adds ethnicity and region controls back into the specification.

3Due to the small number of observations from Black, Asian and other ethnicity backgrounds, we have combined them into one category in the regression model. 
Table S6: Full regressions results for the USA, 2001-20171, 2

\begin{tabular}{|c|c|c|c|c|c|c|c|c|c|c|c|c|}
\hline \multirow[b]{2}{*}{ Explanatory variables } & \multicolumn{3}{|c|}{ Model 1: Age Categories } & \multicolumn{3}{|c|}{$\begin{array}{l}\text { Model 2: Age Categories, Ethnicity } \\
\text { and Regions }\end{array}$} & \multicolumn{3}{|c|}{ Model 3: Continuous Age } & \multicolumn{3}{|c|}{$\begin{array}{l}\text { Model 4: Continuous Age, } \\
\text { Ethnicity and Regions }\end{array}$} \\
\hline & Coeff. & $\begin{array}{l}\text { Std. } \\
\text { error }\end{array}$ & $\begin{array}{l}\text { Odds } \\
\text { ratio }\end{array}$ & Coeff. & $\begin{array}{l}\text { Std. } \\
\text { error }\end{array}$ & $\begin{array}{l}\text { Odds } \\
\text { ratio }\end{array}$ & Coeff. & $\begin{array}{l}\text { Std. } \\
\text { error }\end{array}$ & $\begin{array}{l}\text { Odds } \\
\text { ratio }\end{array}$ & Coeff. & $\begin{array}{l}\text { Std. } \\
\text { error }\end{array}$ & $\begin{array}{l}\text { Odds } \\
\text { ratio }\end{array}$ \\
\hline \multicolumn{13}{|l|}{ LIFE CYCLE (AGE) } \\
\hline Age (continuous) & & & & & & & 0.0341 & 0.0244 & 1.035 & 0.0327 & 0.0243 & 1.033 \\
\hline $\mathrm{Age}^{2} / 100$ & & & & & & & $-0.0531^{* *}$ & 0.0239 & $0.948^{* *}$ & $-0.0505^{* *}$ & 0.0238 & $0.951^{* *}$ \\
\hline $35-44$ years old & -0.159 & 0.135 & 0.853 & -0.145 & 0.135 & 0.865 & & & & & & \\
\hline $45-54$ years old & $-0.446 * * *$ & 0.162 & $0.640^{* * *}$ & $-0.419 * * *$ & 0.162 & $0.658^{* * *}$ & & & & & & \\
\hline 55-64 years old & $-0.332^{*}$ & 0.193 & $0.718^{*}$ & $-0.322^{*}$ & 0.193 & $0.725^{*}$ & & & & & & \\
\hline 65 years and above & $-1.052^{* * *}$ & 0.255 & $0.349^{* * *}$ & $-0.965^{* * *}$ & 0.254 & $0.381^{* * *}$ & & & & & & \\
\hline \multicolumn{13}{|l|}{ HOUSEHOLD STRUCTURE } \\
\hline De facto & $-0.619 * * *$ & 0.216 & $0.538 * * *$ & $-0.622^{* * *}$ & 0.218 & $0.537^{* * *}$ & $-0.604^{* * *}$ & 0.22 & $0.547^{* * *}$ & $-0.608^{* * *}$ & 0.221 & $0.544^{* * *}$ \\
\hline Separated/Divorced & $-0.585^{* * *}$ & 0.123 & $0.557^{* * *}$ & $-0.579 * * *$ & 0.124 & $0.561^{* * *}$ & $-0.604^{* * *}$ & 0.125 & $0.547^{* * *}$ & $-0.596^{* * *}$ & 0.126 & $0.551^{* * *}$ \\
\hline Widowed & -0.479 & 0.293 & 0.619 & $-0.491^{*}$ & 0.291 & $0.612^{*}$ & -0.254 & 0.311 & 0.776 & -0.279 & 0.308 & 0.756 \\
\hline Single/Never married & $-1.036^{* * *}$ & 0.206 & $0.355^{* * *}$ & $-1.008^{* * *}$ & 0.208 & $0.365^{* * *}$ & $-1.008^{* * *}$ & 0.21 & $0.365^{* * *}$ & $-0.976^{* * *}$ & 0.212 & $0.377^{* * *}$ \\
\hline Loss partner while renting & $-1.034^{* * *}$ & 0.19 & $0.356^{* * *}$ & $-1.058^{* * *}$ & 0.19 & $0.347^{* * *}$ & $-1.045^{* * *}$ & 0.194 & $0.352^{* * *}$ & $-1.068^{* * *}$ & 0.193 & $0.344^{* * *}$ \\
\hline Dependent children present & -0.203 & 0.125 & 0.817 & $-0.213^{*}$ & 0.125 & $0.808^{*}$ & $-0.215^{*}$ & 0.123 & $0.806^{*}$ & $-0.224^{*}$ & 0.123 & $0.799 *$ \\
\hline $\begin{array}{l}\text { Had additional dependent } \\
\text { children while renting } \\
\text { HEALTH, WEALTH \& INCOME }\end{array}$ & -0.189 & 0.138 & 0.827 & -0.181 & 0.138 & 0.834 & -0.156 & 0.14 & 0.855 & -0.152 & 0.14 & 0.859 \\
\hline Fair to poor health & -0.194 & 0.143 & 0.824 & $-0.244^{*}$ & 0.143 & $0.783^{*}$ & -0.214 & 0.144 & 0.807 & $-0.261^{*}$ & 0.145 & $0.770^{*}$ \\
\hline Highest qualification: Tertiary & $0.408^{* * *}$ & 0.114 & $1.504^{* * *}$ & $0.393^{* * *}$ & 0.113 & $1.481^{* * *}$ & $0.409^{* * *}$ & 0.115 & $1.505^{* * *}$ & $0.393^{* * *}$ & 0.114 & $1.481^{* * *}$ \\
\hline Employed & $0.302^{* *}$ & 0.128 & $1.352^{* *}$ & $0.314^{* *}$ & 0.128 & $1.369^{* *}$ & $0.294^{* *}$ & 0.128 & $1.342^{* *}$ & $0.302^{* *}$ & 0.128 & $1.353^{* *}$ \\
\hline $\begin{array}{l}\text { Loss of employment while } \\
\text { renting }\end{array}$ & $-0.926^{* * *}$ & 0.141 & $0.396^{* * *}$ & $-0.978^{* * *}$ & 0.141 & $0.376^{* * *}$ & $-0.941^{* * *}$ & 0.143 & $0.390^{* * *}$ & $-0.999 * * *$ & 0.144 & $0.368^{* * *}$ \\
\hline User cost from last observation & -0.119 & 0.0963 & 0.888 & -0.124 & 0.0952 & 0.883 & -0.0911 & 0.0988 & 0.913 & & & 0.905 \\
\hline $\begin{array}{l}\text { Real amount of equity release } \\
\text { upon selling up }\end{array}$ & & & & & & 0.883 & -0.0911 & 0.0988 & 0.913 & -0.0997 & 0.0974 & 0.905 \\
\hline (AU\$/E/US\$00,000) & $0.0805^{* *}$ & 0.0357 & $1.084^{* *}$ & $0.108^{* * *}$ & 0.0364 & $1.114^{* * *}$ & $0.0847^{* *}$ & 0.0366 & $1.088^{* *}$ & $0.113^{* * *}$ & 0.0373 & $1.119^{* * *}$ \\
\hline $\begin{array}{l}\text { Received inheritance in the last } \\
\text { financial year } \\
\text { HOUSING }\end{array}$ & $0.956^{* *}$ & 0.427 & $2.600^{* *}$ & $1.096^{* *}$ & 0.429 & $2.992^{* *}$ & $0.955^{* *}$ & 0.431 & $2.599 * *$ & $1.086^{* *}$ & 0.433 & $2.963^{* *}$ \\
\hline Social housing & -0.00149 & 0.293 & 0.999 & -0.00576 & 0.296 & 0.994 & 0.00421 & 0.295 & 1.004 & 0.00751 & 0.298 & 1.008 \\
\hline $\begin{array}{l}\text { Rent-free } \\
\text { CALENDAR YEAR }\end{array}$ & $0.363^{* * *}$ & 0.129 & $1.438^{* * *}$ & $0.331^{* *}$ & 0.13 & $1.392^{* *}$ & $0.382^{* * *}$ & 0.131 & $1.466^{* * *}$ & $0.348^{* * *}$ & 0.132 & $1.417^{* * *}$ \\
\hline 2005 & -0.236 & 0.251 & 0.790 & -0.267 & 0.25 & 0.765 & -0.197 & 0.254 & 0.821 & -0.230 & 0.253 & 0.795 \\
\hline 2007 & $-0.525^{* *}$ & 0.246 & $0.592^{* *}$ & $-0.558^{* *}$ & 0.244 & $0.572^{* *}$ & $-0.486^{*}$ & 0.248 & $0.615^{*}$ & $-0.523^{* *}$ & 0.247 & $0.593^{* *}$ \\
\hline 2009 & $-0.815^{* * *}$ & 0.244 & $0.443^{* * *}$ & $-0.833^{* * *}$ & 0.243 & $0.435^{* * *}$ & $-0.766^{* * *}$ & 0.247 & $0.465^{* * *}$ & $-0.789^{* * *}$ & 0.245 & $0.454^{* * *}$ \\
\hline 2011 & $-0.762^{* * *}$ & 0.25 & $0.467^{* * *}$ & $-0.767^{* * *}$ & 0.248 & $0.464^{* * *}$ & $-0.693^{* * *}$ & 0.253 & $0.500^{* * *}$ & $-0.703^{* * *}$ & 0.251 & $0.495^{* * *}$ \\
\hline 2013 & $-0.652^{* *}$ & 0.27 & $0.521^{* *}$ & $-0.669 * *$ & 0.268 & $0.512^{* *}$ & $-0.566^{* *}$ & 0.274 & $0.568^{* *}$ & $-0.589^{* *}$ & 0.272 & $0.555^{* *}$ \\
\hline 2015 & $-0.815^{* * *}$ & 0.281 & $0.443^{* * *}$ & $-0.804^{* * *}$ & 0.279 & $0.448^{* * *}$ & $-0.743^{* * *}$ & 0.286 & $0.475^{* * *}$ & $-0.736^{* * *}$ & 0.283 & $0.479^{* * *}$ \\
\hline
\end{tabular}




\begin{tabular}{|c|c|c|c|c|c|c|c|c|c|c|c|c|}
\hline \multirow{5}{*}{$\begin{array}{l}\text { Explanatory variables } \\
\text { ETHNICITY } \\
\text { Black } \\
\text { Other }{ }^{3} \\
\text { GEOGRAPHICAL DIVISION }\end{array}$} & \multicolumn{3}{|c|}{ Model 1: Age Categories } & \multicolumn{3}{|c|}{$\begin{array}{l}\text { Model 2: Age Categories, Ethnicity } \\
\text { and Regions }\end{array}$} & \multicolumn{3}{|c|}{ Model 3: Continuous Age } & \multicolumn{3}{|c|}{$\begin{array}{l}\text { Model 4: Continuous Age, } \\
\text { Ethnicity and Regions }\end{array}$} \\
\hline & Coeff. & $\begin{array}{l}\text { Std. } \\
\text { error }\end{array}$ & $\begin{array}{l}\text { Odds } \\
\text { ratio }\end{array}$ & Coeff. & $\begin{array}{l}\text { Std. } \\
\text { error }\end{array}$ & $\begin{array}{l}\text { Odds } \\
\text { ratio }\end{array}$ & Coeff. & $\begin{array}{l}\text { Std. } \\
\text { error }\end{array}$ & $\begin{array}{l}\text { Odds } \\
\text { ratio }\end{array}$ & Coeff. & $\begin{array}{l}\text { Std. } \\
\text { error }\end{array}$ & $\begin{array}{l}\text { Odds } \\
\text { ratio }\end{array}$ \\
\hline & & & & 0.0568 & 0.189 & 1.058 & & & & 0.00992 & 0.192 & 1.010 \\
\hline & & & & 0.332 & 0.25 & 1.393 & & & & 0.314 & 0.254 & 1.369 \\
\hline & & & & & & & & & & & & \\
\hline New England & & & & 0.0502 & 0.303 & 1.052 & & & & 0.000101 & 0.307 & 1.000 \\
\hline Middle Atlantic & & & & -0.109 & 0.199 & 0.896 & & & & -0.0820 & 0.203 & 0.921 \\
\hline East North Central & & & & 0.124 & 0.179 & 1.132 & & & & 0.120 & 0.182 & 1.128 \\
\hline West North Central & & & & 0.306 & 0.196 & 1.358 & & & & 0.329 & 0.2 & 1.389 \\
\hline East South Central & & & & $0.576^{* * *}$ & 0.211 & $1.779^{* * *}$ & & & & $0.620^{* * *}$ & 0.214 & $1.859^{* * *}$ \\
\hline West South Central & & & & $0.500^{* * *}$ & 0.179 & $1.649^{* * *}$ & & & & $0.522^{* * *}$ & 0.182 & $1.685^{* * *}$ \\
\hline Mountain & & & & 0.229 & 0.2 & 1.257 & & & & 0.243 & 0.203 & 1.275 \\
\hline Pacific & & & & -0.224 & 0.185 & 0.799 & & & & -0.213 & 0.189 & 0.808 \\
\hline Constant & 0.508 & 0.504 & 1.662 & 0.355 & 0.514 & 1.426 & -0.280 & 0.824 & 0.756 & -0.401 & 0.826 & 0.669 \\
\hline Observations & 2,963 & & & 2,936 & & & 2,963 & & & 2,936 & & \\
\hline Number of individuals & 1,147 & & & 1,138 & & & 1,147 & & & 1,138 & & \\
\hline Wald-chi2 & $227.12^{* * *}$ & & & $241.30^{* * *}$ & & & 221.21 & & & $235.56^{* * *}$ & & \\
\hline LR test of rho $=0$ & $3.23^{* *}$ & & & $1.86^{*}$ & & & $4.41^{* *}$ & & & $2.76^{* *}$ & & \\
\hline
\end{tabular}

Source: Authors' calculations using the 2001-2017 PSID.

Notes:

*** significant at $1 \%$ level, ${ }^{* *}$ significant at $5 \%$ level, and * significant at $10 \%$ level.

1The omitted reference categories are: $<35$ years old, married, did not lose a partner while renting, no dependent children, did not have additional dependent children while

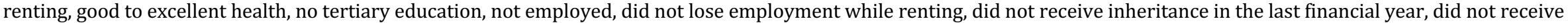
a parental gift of AU $\$ 5000$ or more, and private renters, white ethnic background, from the South Atlantic region, and year 2003.

2We experimented with various specifications that allow for alternative definitions of age, the inclusion or otherwise of ethnicity and geographical (region) controls:

- Column 1 reports estimates on omitting ethnicity and region controls and employing age categories.

- Column 2 adds ethnicity and region controls.

- Column 3 omits ethnicity and region controls but replaces age categories by a continuous version of age.

- Column 4 adds ethnicity and region controls back into the specification.

30ther ethnicity backgrounds include Hispanics and other ethnicity backgrounds. 


\section{REFERENCES (CITED IN SUPPLEMENTARY MATERIALS)}

Booth AL and Katic P (2011) Estimating the wage elasticity of labour supply to a firm: what evidence is there for monopsony? Economic Record 82(278): 359-369.

McGonagle K., Schoeni R, Sastry N and Freedman VA (2012) The Panel Study of Income Dynamics: Overview, recent innovations, and potential for life course research. Longitudinal and Life Course Studies 3(2): 268-284. https://doi.org/10.14301/llcs.v3i2.188

Mendolia S and Siminski P (2016) New estimates of intergenerational mobility in Australia. Economic Record 92(298): 361-373.

Smith SJ, Cigdem M, Ong R and Wood G (2017) Wellbeing at the edges of ownership, Environment and Planning A 49(5): 1080-1098.

Watson N (2011) Methodology for the HILDA top-up. HILDA Project Technical Paper Series No. 1/11, September. Melbourne Institute of Applied Economic and Social Research, University of Melbourne. Retrieved from

https://melbourneinstitute.unimelb.edu.au/assets/documents/hildabibliography/hilda-technical-papers/htec111.pdf

Watson N, Leissou E, Guyer H, Wooden M (2019) Best practices for panel maintenance and retention. In: Johnson, T.P., Pennell, B.-E., Stoop, I.A.L., Dorer, B. (Eds.), Advances in Comparative Survey Methods: Multicultural, Multinational and Multiregional Contexts (3MC), Wiley, New York, pp. 597-622.

Watson N and Wooden M (2020) The Household, Income and Labour Dynamics in Australia (HILDA) Survey. Journal of Economics and Statistics https://doi.org/10.1515/jbnst-2020-0029 